\title{
BLACK SEA ECONOMIC CO-OPERATION (BSEC): PROPOSALS AND POSSIBILITIES WITH PARTICULAR REFERENCE TO THE EU*
}

\author{
Muzaffer DARTAN**
}

\begin{abstract}
From the ashes of the disintegration of the USSR a patchwork of regional organisations grew up, stretching from Central and Eastern Europe and extending into the former Soviet Union. Neighbouring countries which had, until then, been excluded from such arrangements came to covet membership of these regional groupings. The countries left out of this process have come together to form their own economic co-operation project - the Black Sea Economic Co-operation (BSEC). The majority of BSEC members comprise the former socialist satellite republics of the Soviet Union. Typically, they are fighting the serious economic, social and political problems posed by the transition to market economies. Naturally, the EU has lately become the focus of these countries' ambitions and aspirations. The EU has a reciprocal interest in the $B S E C$. Abundant natural resources make the BSEC of special interest to the EU. The integration of the BSEC states is significant for the EU not only economically reasons but also for reasons of security.
\end{abstract}

\section{Introduction}

The collapse of the Soviet Union found its former republics and satellites bereft of any kind of efficient economic co-operation apparatus. Consequently, these new countries have embarked upon the BSEC project - a project to bring them together in a loose regional economic grouping with the aim of strengthening their economic

* I would like to thank Mr Hywel Rees for his technical assistance in English, and Mrs Süreyya Cansoy and Mr Armağan Çakır for collecting data.

"* Associate Professor, Marmara University EC Institute [e-mail: mdartan@marun.edu.tr] 
ties. Before dealing with the BSEC it is interesting to look at other regional groupings, established in Central and Eastern Europe and in the former soviet Union during the 1990 s.

\section{a) Central and Eastern Europe}

The Trilateral Co-operation (Visegrád Treaty). This grouping was instituted in February 1990 by Hungary, Czechoslovakia and Poland. When an associated free trade agreement was signed in 1992, the association was renamed the European Free Trade Association (CEFTA). 1

The Central European Initiative (CEI). This grouping was established in August 1990 by Austria, Hungary, Italy and Yugoslavia. Poland joined in 1991 followed by Slovenia, Croatia and Bosnia-Herzegovina in 1992. Macedonia joined in 1993.2

Both of these arrangements were established to prepare their members for eventual accession to the EU and for the structural and institutional discipline that accession will involve.

\section{b) The Former Soviet Union}

The Commonwealth of Independent States (CIS). The CIS was established by the majority of the successor states of the former Soviet Union. Within the CIS, Moscow dictates both economic and military policy as well as directing foreign relations. Moscow's ambitions for the CIS are for it to become an influential regional power, akin in many ways to the former USSR in economic and political terms. The reality, however, is that the CIS is merely the institution through which Russia maintains its bilateral relations with the other CIS member states. The existence of the CIS does not, however, preclude regional arrangements between individual member state. Indeed, a number of these smaller regional groupings have arisen within the CIS. For example, since January 1995, Belarus, Russia, Kazakhstan and Kyrgyzstan have enjoyed a customs union - a grouping known as the Community of Integrated States. Since 1994, Kazakhstan, Kyrgyzstan and Uzbekistan joined in a similar arrangement. ${ }^{3}$

Although the Soviet Union had broken up, the new states which emerged in its place had much in common with one another and, often, similar economic interests. The newly independent states had, after all, endured 70 years of centrally planned economic policy. Indeed, because of the way in which the old Soviet economy had been organised, few of its successor states were economically independent. Whilst old trade links could not easily be dispensed with, however, these states needed improved economic and trade relations with the developed world if they were to develop structurally and institutionally. In particular, they needed new investment something only the developed world could provide - and access to the developed world's lucrative markets. These two imperatives combined to produce the CIS. The 
CIS quickly became a Moscow dominated forum, acting more in the interest of Russia than in the interests of its former satellites. It was in an effort to supplant the $\mathrm{CIS}$ with an organisation more in tune with the needs and aspirations of the former Soviet republics that work began to develop an alternative co-operative framework between these states. ${ }^{4}$

Some of the regional groupings formed after the collapse of the Soviet Union have only ever really existed on paper. The Community of Integrated States (comprising Russia, Belarus, Kazakhstan and Kyrgyzstan) for example, is one such case. ${ }^{5}$

\section{c) Central Asia}

The Economic Co-operation Organisation (ECO), comprising Turkey, Pakistan and Iran has enjoyed little success since its revival in 1992 (it was born in 1965 as the Regional Co-operation for Development but failed due to its reluctance to liberalise trade between member states). ECO's revival in 1992 coincided with a broadening of its membership to include Kazakhstan, Kyrgyzstan, Tajikistan, Turkmenistan, Uzbekistan, Azerbaijan (the only transcaucasian state admitted) and Afghanistan.

ECO's economic significance as a trading bloc may be interpreted in two ways. Its promoters point to its 300 million strong population, vast natural resources and strong labour force. This combination makes the organisation potentially very powerful indeed. ECO's detractors, however, point to its low regional and global profile, arguing that ECO members will remain impotent as a bloc because of their poor past economic performance and their political and ideological differences exemplified by Iran's Islamic fundamentalism and Turkey's secular liberalism. ${ }^{6}$

\section{d) The Balkans, Transcaucasian and the Former Soviet Union}

The Black Sea Economic Co-operation. Late 1990 marks the beginning of economic co-operation in the Black Sea region; the initial protagonists being the USSR, Bulgaria, Romania and Turkey. The dramatic developments of 1991 added further impetus to this process, extending the Co-operation to the Balkans and into the Caucasus - 11 states in all. The first meeting of the Black Sea Economic Cooperation (BSEC) was held in Ankara in December 1990 and this meeting set the agenda for further rounds of BSEC discussions. That first meeting was attended by Turkey, the Russian Federation, Romania, Bulgaria and five former states of the USSR, namely, Armenia, Azerbaijan, Georgia, Moidova and Ukraine. Turkey prepared a draft document and a working group of participating states met in Bucharest in March 1991, Sofia in the following April and finally in Moscow in July that year. Both Greece and the former Yugoslavia attended the Moscow meeting as observers. 


\section{The BSEC Project - A New Model?}

What is meant by regional co-operation and regional integration? Regional integration refers to a unification of markets, mutual trade preferences, harmonisation of economic policy and the free flow of capital and labour. Regional co-operation is a much looser concept, with emphasis again being placed on infrastructure, resources and broad issues of policy. Regional co-operation is better suited to the BSEC because it is more flexible. Its purpose is to remove obstacles to free trade and to minimise regulation between states.

Economic integration takes various forms, but the simplest in the creation of a free trade zone in which tariffs are abolished between member states but each maintains its own external tariff. A customs union is similar but each state adopts a common external tariff. The next stage is a common market in which restrictions on the mobility of goods, services capital and labour are abolished - the "four freedoms". Physical and technical barriers are removed as well as fiscal barriers, for example, by harmonising tax rates. Full economic integration involves the unification of policy and demands supranational institutions to manage it.

The BSEC does not fit easily into any of traditional models of economic cooperation. Its form has arisen out of the needs of its members and their desire to liberalise and develop their relations with each other. Their geographical proximity, traditional ties and broadly similar markets make them well placed to complete the transformation into dynamic market economies. Despite the economic and political instability of many of its member states, the raison d'être of the BSEC is a strong one, lending it a relatively strong political base.

The scope of the BSEC may fairly be said to be broad, yet it places great emphasis on making the best use of its human, financial and natural resources. The harmonisation of policy is not one of the BSEC's objectives and there is no question of supranationality.

Free market conditions do not yet exist throughout the whole of the BSEC. Member states' currencies are not compatible with one another and prices often fail to accurately reflect economic cost. A free trade area is too ambitious an aim at this early stage.

Goals and Principles of the BSEC Project. There are four principal driving forces behind the BSEC project. Firstly, its members hope to achieve an improved level of integration of their economies into the world economy. Secondly, each member seeks to make the best use of its geographical proximity to its fellow member states. Thirdly, BSEC members aim to support one another in the difficult transition to liberal, market economies. Finally and most importantly, the BSEC aims to foster peace, prosperity and stability in the region as a whole. Peace and stability, above all 
things, will enable the region to develop and expand its trade and economies. The recent crisis makes this goal particularly important (See the BSEC Declaration in the Appendix I).

\section{Institutional Structure of the BSEC}

There are four pillars to the institutional structure of the BSEC. The legislature, the executive, the private sector, and Black Sea Trade and Development Bank (the Bank). All play their part in supporting and developing the BSEC. Non-governmental and academic institutions may also make a contribution (See Figure II).

\section{a) Executive}

The Meeting of the Ministers of Foreign Affairs (MMFA) is the executive branch of the BSEC. Its sessional chairmanship rotates every sixth month in alphabetical order. The day-to-day management of the BSEC is left to the Senior Officials Meeting, permanent working groups currently over spheres such as economic statistics, finance and trade co-operation, agriculture, infrastructure and energy. The ad hoc working groups deal with minor matters, such as travel facilities for businessmen and the promotion of investment and protection of property rights.

Istanbul hosts the Permanent International Secretariat of the BSEC. Its mandate is principally of a bureaucratic and technical nature - preparing drafts of BSEC documents, for example. The Secretariat also provides administrative support to member states, maintains the archive of the BSEC and provides a similar service to subsidiary bodies of the BSEC.

\section{b) Legislatur}

The BSEC has a parliament of sorts. The chairmen of the national assemblies of nine out of the 11 member states signed, in February 1993, the Declaration of the Parliamentary Assembly of the BSEC (PABSEC). Greece and Bulgaria did not join PABSEC until later.

The PABSEC is attended by 70 representatives of the participating national assemblies, each holding its seat for one year (allocation of seats by member states in Table I). The heads of the member states' assemblies rotate the chairmanship of the PABSEC in turn. Through the PABSEC, the BSEC has gained the means to properly reflect its co-operative aspirations to both the public and its constituent national assemblies. Further, the PABSEC underlines the importance placed on political co-operation within the PABSEC, though the PABSEC is not, of course, a supranational assembly. Its chief role is to recommend that national governments make certain rules within the BSEC to enhance co-operation and to conduct studies aimed at assessing how best to promote political stability in the region. 
Figure II: Institutional Structure of the Black Sea Economic Co-operation

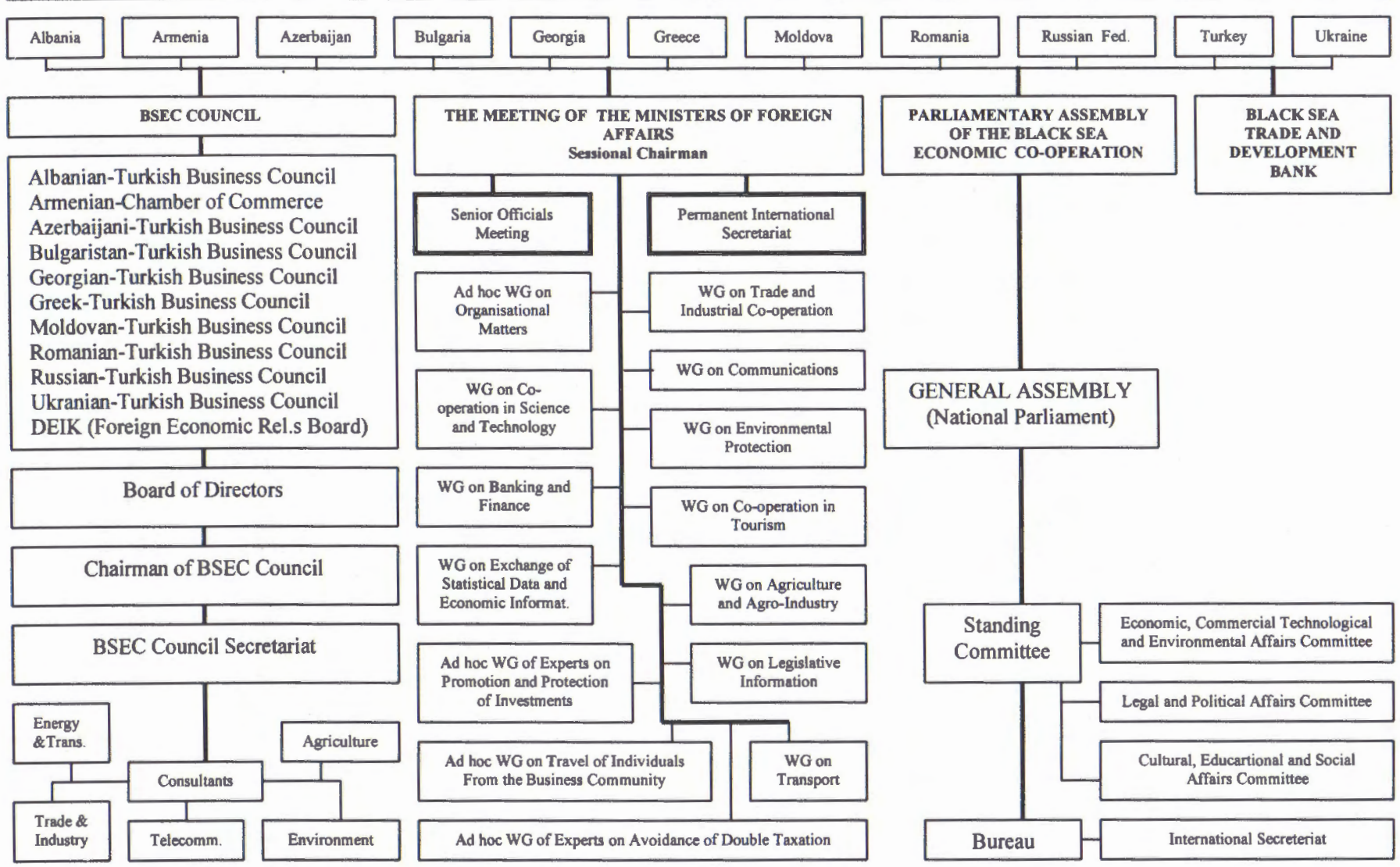

Source: BSEC Permanent International Secretariat (1994), The BSEC: The Present and the Future, Istanbul, p.23. 
Table I: Composition of the Parliamentary Assembly of BSEC

\begin{tabular}{|c|c|c|}
\hline $\begin{array}{l}\text { Country Groups } \\
\text { Acccording to Demographic Criteria }\end{array}$ & $\begin{array}{l}\text { Members for each } \\
\text { Country }\end{array}$ & Total \\
\hline \multicolumn{3}{|l|}{$1^{\text {st }}$ Group: Between 1 and 5 millions } \\
\hline Albania & 4 & \\
\hline Armenia & 4 & 12 members \\
\hline Moldova & 4 & \\
\hline \multicolumn{3}{|l|}{$2^{\text {nd }}$ Group: Between 5 and 10 millions } \\
\hline Georgia & $5(4+1)$ & \\
\hline Azerbaijan & 5 & 15 members \\
\hline Bulgaria & 5 & \\
\hline \multicolumn{3}{|l|}{$3^{\text {rd }}$ Group: Between 10 and 20 millions } \\
\hline $10.5 \mathrm{~m}$ & $6(4+2)$ & 6 members \\
\hline \multicolumn{3}{|l|}{$4^{\text {th }}$ Group: Between 20 and 50 millions } \\
\hline Romania & $7(4+3)$ & 7 members \\
\hline \multicolumn{3}{|l|}{$5^{\text {th }}$ Group: Between 50 and 100 millions } \\
\hline $50.7 \mathrm{~m}$. & $9(4+5)$ & 18 members \\
\hline $62.5 \mathrm{~m}$. & 9 & \\
\hline \multicolumn{3}{|l|}{$6^{\text {th }}$ Group: 100 millions and over } \\
\hline $147.3 \mathrm{~m}$ & $12(4+8)$ & 12 members \\
\hline
\end{tabular}

Source: PABSEC. 
Figure II illustrates how the three committees of the PABSEC debate issues and report to the General Assembly. The Committee reports on a wide range of matters of concern to the General Assembly.

The PABSEC itself is supported by the Bureau for the Assembly and the Standing Committee comprising the heads of the national delegations to the assembly, members of the Bureau and the chairmen of each of the three committees. The structure of the PABSEC also includes the International Secretariat, headed by the Secretary General.

\section{c) The Council of the BSEC}

The Council of the BSEC is the body through which the private sector contributes to the BSEC decision making process. The private sector's contribution to the BSEC is a crucial one. Great emphasis is placed on the improvement of the business environment within the BSEC. The BSEC Council was founded in 1992 and is run by a Board of Directors whose chairmanship rotates every six months. The Council's purpose is to identify potential public investment projects and to recommend them to BSEC members for support, co-operating with the International Secretariat in Istanbul.

\section{d) The Black Sea Trade and Development Bank}

The Bank is the financial element of the BSEC. It was established in January 1995 and its mandate is to "contribute effectively to the transition process of the member states towards the economic prosperity of the people of the region and to finance and promote regional projects and provide other banking services to projects and private sectors and trade activities among the members states". The Bank's purposes are many and varied, fitting into four main categories:8

- To assist in the promotion of private business initiatives, to support private commercial enterprise and to foster intra-regional trade.

- To finance or facilitate the financing of commercial activity in the BSEC region and to assist in the funding of multilateral institutions. This head is extremely broad in its scope.

- To foster, through its activities, the economic and social development of the region, giving special consideration to projects aimed at improving the welfare of the people of the region.

- To undertake studies of the region and to offer support and advice to member states as a means of improving economic policy-making. It is further charged with identifying suitable infrastructure projects and suggesting ways in which they might be financed. 
In broad terms, then, the Bank is an international development bank with a very wide remit to promote the success of the BSEC project. The Bank facilitates financial co-operation in both the public and private sectors in the BSEC and also to those outside the region seeking to do business with BSEC members. The Bank may also prove to be a valuable conduit of funds from agencies such as the European Bank for Reconstruction and Development (EBRD). ${ }^{9}$ Indeed, the EBRD is already an observer in the BSEC.

The Bank's headquarters are located in Thessalonika and it has operated since 1996. The unit of account of the Bank is the Special Drawing Right (SDR). The Bank's initial authorised capital was $\$ 1.5 \mathrm{bn}$, or SDR I bn. Each member state is entitled to subscribe for the Bank's capital in the following proportions (see Figure III).

\section{Dealing With Difficulties Within the BSEC}

If the BSEC project is to succeed, significant economic and political obstacles will need to be overcome. The most important of these obstacles may be summarised as follows: 10

\subsection{Political Stability}

Throughout the Cold War, the superpowers had maintained political stability in the Black Sea region. Since the end of the Cold War, much of the military tension between the rival alliances has dissipated, but this change has also unleashed longstanding grievances between the former Soviet satellites. These changes fundamentally altered the balance of power in the entire region. Flashpoints of ethnic hatred, nationalism, religious tension and territorial dispute have erupted all over the region. Some of these have already turned into bloody conflict, notably in Yugoslavia, Chechnya. Nagorno-Karabakh and Georgia.

\section{a) The Yugoslav Conflict}

The Balkans have, for centuries, been a cross-roads of ethnicity and one of the principal trade routes from east to west. This unfortunate geo-political inheritance has led, in the past, to countless wars. The most recent of the Balkan conflicts, in BosniaHerzegovina and Kosovo, have proved a bloody illustration of the ethnic complexity of the region. Whilst the Dayton Accord broke the viscous circle of military conflict in Bosnia, the underlying problems of the region remain to be resolved and the Kosovo conflict remains wholly unchecked. The former Yugoslavia looks set to remain high on the international agenda for some time to come.

\section{b) Trans-Dniester}

This territorial dispute between Moldova and Russia has stabilised under a deal which exchanged land for autonomy. 
Figure III: Shares of the Member States to the Initial Capital Stock of BSTDB

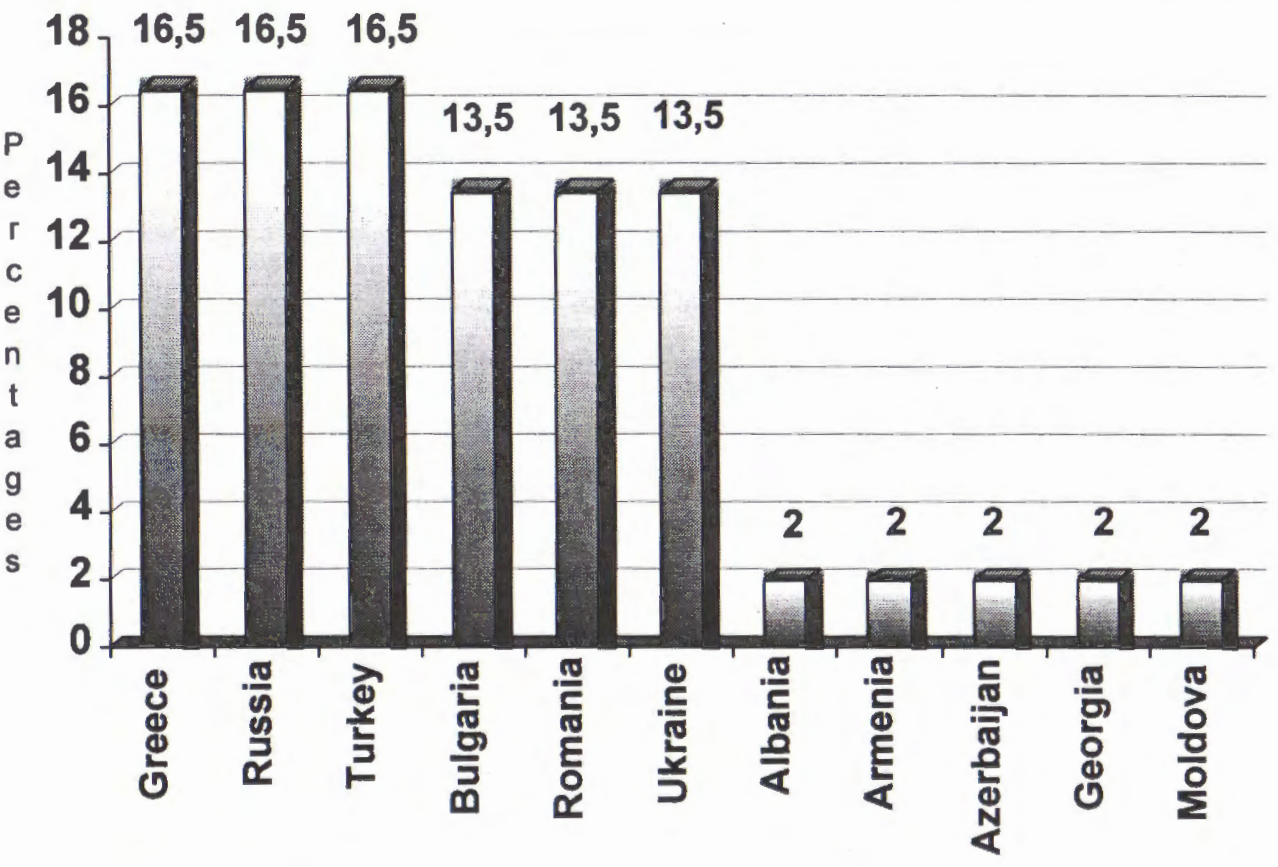




\section{c) The Crimea}

The whole of the Crimea is the cause of some tension between Ukraine and Russia. Armed conflict is unlikely, but the risk remains

\section{d) The Black Sea Fleet}

The Black Sea Fleet has, since the demise of the Soviet Union, become a matter of great contention between Ukraine and Russia. The Black Sea Fleet was and is the principal naval defence force in the Black Sea region and was the Soviet Union's chief military presence in the Mediterranean. To whom the Fleet belonged, how it should be financed and where it should be based, were all pressing questions confronting the two countries who sought to argue over its ownership. An agreement has since been reached, however, on this contentious issue.

\section{e) Chechnya}

Although there is a semblance of peace in that country, no lasting solution to the underlying problems has yet emerged. The war there weakened Russia and brought chaos and destruction to Chechny.

\section{f) Abkhazia}

The inter-ethnic civil war between the Ossetians and the Abkhazians in Georgia continues to rumble and destabilise the region. An uneasy calm has been achieved but could break down completely with little warning.

\section{g) Nagorno-Karabakh}

This issue dominates the political life of every Azeri. Karabakh is an enclave of Armenian territory landlocked by Azerbaijan. War broke out when Karabakhi Armenians voted to break away from Azerbaijan and join neighbouring Armenia. The Armenians adopted a policy of ethnic cleansing in the enclave, making refugees of the Azeri minority. Azerbaijan tried and failed to recover the territory of Karabakh, losing further in the process. Fighting came to an end in May 1994 but not before 20.000 had died and 850.000 Azeris made homeless. ${ }^{11}$

\section{h) Greece and Turkey}

Like most problems this region, antagonism between Greece and Turkey is hugely complex and of long-standing. The three main areas of discord may be summarised as follows.

Firstly, Cyprus. The island is currently divided between the Turkish North and Greek South. Each group is kept apart by a UN administered demilitarised zone. No solution has yet been reached on this issue. 
Secondly, the Aegean. The Aegean is a crowded sea with many closely packed islands. Greece insists that its territorial waters around each island should be increased to 12 miles whilst Turkey insists that the limit remain at 6 miles. As many Greek islands lie very near the Turkish coastline, an extension of Greece's territorial limit would intertere with Turkish shipping and commerce. Greece also claims control of the Aegean flight corridor and contends that the continental shelf of Anatolia should properly be the continental shelf of the Aegean islands.

This would have serious implications for the ownership of those natural resources which are thought to lie beneath the Aegean. Other problems in the Aegean include the dispute over possession of a few tiny island and the increasing militarisation of the Aegean by Greek forces, in contravention of the Lausanne Treaty.

Finally, Western Thrace. The Turkish minority in Western Thrace is prevented from expressing its ethnicity - a blatant attempt by the Greeks to suppress the human rights of ethnic Turk.

It is easy to conclude, from this litany of antagonism, that the BSEC is not based upon the mutual trust of its members. Indeed, all of these issues somewhat overshadowed the economic issues at the birth of the BSEC. Eduard Schverdnatze, the Georgian Premier, had sought to establish a committee whose business it would have been to oversee and encourage the protection of human rights within the BSEC. He also proposed reductions in military forces in the area. Such proposals were too ambitious, however, and such issues are unlikely to be addressed until economic prosperity and political security are assured. The BSEC is driven by an economic, rather than a political, imperative.

\subsection{Economic Stability}

The BSEC covers a market of 325 million people and an area of $19.2 \mathrm{~m} \mathrm{sq.km}$ (see Table II). Despite enjoying prolific natural resources, however, the industrial potential of the region is difficult to assess. In particular, it is impossible to say when any of the former socialist republics may start irreversibly down the path to sustainable development.

\section{a) Transition to Market Economy}

The BSEC remains, for the time being, an agglomeration mostly of the weak and poor. Most of its members are underdeveloped and much of their industry is obsolete and uncompetitive. Even the Greek economy has some way to go, despite its membership of the EU and the concomitant benefits and subsidies it receives as a consequence. 12 
Table II: Economic Indicators of the BSEC Member Countries

\begin{tabular}{|c|c|c|c|c|c|c|c|c|c|}
\hline Country & $\begin{array}{l}\text { Real } \\
\text { GDP } \\
\text { Growth } \\
(\%)\end{array}$ & $\begin{array}{l}\text { Origins of GDP } \\
\text { (\% in total) })^{1}\end{array}$ & & $\begin{array}{l}\text { Export } \\
(\text { fob })^{2} \\
(\mathrm{~S} \mathrm{~m})\end{array}$ & 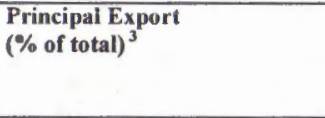 & & $\begin{array}{l}\text { Import } \\
(\text { fob })^{4} \\
(\mathrm{~S} \mathrm{~m})\end{array}$ & 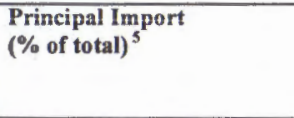 & \\
\hline $\begin{array}{l}\text { Albania } \\
\text { (1996) }\end{array}$ & $\begin{array}{r}9.1 \\
-7.0\end{array}$ & $\begin{array}{l}\text { Agriculture } \\
\text { Industry } \\
\text { Services }\end{array}$ & $\begin{array}{l}51.5 \\
12.2 \\
36.3\end{array}$ & 158.6 & $\begin{array}{l}\text { Manufactured goods } \\
\text { Crude materials, except fuel } \\
\text { Food, beverages, tobacco \& } \\
\text { Live animals } \\
\text { Fuels \& lubricants }\end{array}$ & $\begin{array}{l}64.9 \\
16.9 \\
8.9 \\
4.1\end{array}$ & 693.5 & $\begin{array}{l}\text { Manufactured goods } \\
\text { Food, beverages, tobacco \& } \\
\text { Live animals } \\
\text { Machinery \& transport } \\
\text { equipment } \\
\text { Chemical products }\end{array}$ & $\begin{array}{r}32.8 \\
32.0 \\
25.0 \\
5.9\end{array}$ \\
\hline Armenia & 3.1 & $\begin{array}{l}\text { Agriculture \& Forestry } \\
\text { Industry } \\
\text { Trade } \\
\text { Construction } \\
\text { Transport \& } \\
\text { Communications }\end{array}$ & $\begin{array}{r}40.4 \\
30.4 \\
8.3 \\
6.3 \\
\\
4.4\end{array}$ & 232 & $\begin{array}{l}\text { Non-precious metals } \\
\text { Jewellery } \\
\text { Machinery \& equipment }\end{array}$ & $\begin{array}{l}25 \\
24 \\
14\end{array}$ & 793 & $\begin{array}{l}\text { Raw materials } \\
\text { Vegetable products } \\
\text { Machinery \& equipment }\end{array}$ & $\begin{array}{l}24 \\
12 \\
11\end{array}$ \\
\hline Azerbaijan & 5.8 & $\begin{array}{l}\text { Agriculture } \\
\text { Industry } \\
\text { Construction } \\
\text { Transport \& } \\
\text { Communications } \\
\text { Trade }\end{array}$ & $\begin{array}{r}20.0 \\
24.8 \\
13.8 \\
\\
11.9 \\
5.5\end{array}$ & 808 & $\begin{array}{l}\text { Oil products } \\
\text { Cotton } \\
\text { Chemicals, petrochemicals \& } \\
\text { plastics } \\
\text { Food industry } \\
\text { Machinery }\end{array}$ & $\begin{array}{r}480.1 \\
123.3 \\
\\
59.9 \\
55.3 \\
37.4\end{array}$ & 1,375 & $\begin{array}{l}\text { Machinery \& equipment } \\
\text { Food industry } \\
\text { Metals } \\
\text { Oil products } \\
\text { Chemicals \& Petrochemicals }\end{array}$ & $\begin{array}{r}169.0 \\
180.7 \\
109.4 \\
79.2 \\
78.7\end{array}$ \\
\hline Bulgaria & -6.9 & $\begin{array}{l}\text { Agriculture forestry } \\
\text { Industry } \\
\text { Trade \& Services }\end{array}$ & $\begin{array}{l}26.2 \\
29.4 \\
44.4\end{array}$ & 4,927 & $\begin{array}{l}\text { Base metals } \\
\text { Chemicals } \\
\text { Textiles } \\
\text { Machinery \& transport } \\
\text { equipment } \\
\text { Animal \& vegetable products } \\
\text { Mineral products \& furls }\end{array}$ & $\begin{array}{r}1,046 \\
911 \\
798 \\
719 \\
699 \\
501\end{array}$ & $-4,558$ & $\begin{array}{l}\text { Mineral products \& fuels } \\
\text { Machinery \& transport } \\
\text { equipment } \\
\text { Textiles } \\
\text { Chemicals } \\
\text { Animal \& vegetable prod. } \\
\text { Base metals }\end{array}$ & $\begin{array}{l}1,797.1 \\
859.3 \\
706.3 \\
593.3 \\
428.5 \\
299.2 \\
\end{array}$ \\
\hline Georgia & 11,3 & $\begin{array}{l}\text { Agriculture } \\
\text { Industry } \\
\text { Construction } \\
\text { Transport \& } \\
\text { communications } \\
\text { Trade }\end{array}$ & $\begin{array}{r}28.4 \\
9.7 \\
4.8 \\
10.0 \\
22.1\end{array}$ & 230 & $\begin{array}{l}\text { Metals } \\
\text { Food, drink \& tobacco products } \\
\text { Chemicals }\end{array}$ & $\begin{array}{l}21.5 \\
20.7 \\
10.7\end{array}$ & 931 & $\begin{array}{l}\text { Mineral products } \\
\text { Food, drink \& tobacco } \\
\text { products } \\
\text { Machinery }\end{array}$ & $\begin{array}{r}28.6 \\
20.0 \\
10.0\end{array}$ \\
\hline
\end{tabular}


Table II (Continued)

\begin{tabular}{|c|c|c|c|c|c|c|c|c|c|}
\hline Country & $\begin{array}{l}\text { Real } \\
\text { GDP } \\
\text { Growth } \\
(\%)\end{array}$ & $\begin{array}{l}\text { Origins of GDP } \\
\text { (\% in total) }\end{array}$ & & $\begin{array}{l}\text { Export } \\
\text { (fob) } \\
(\mathrm{S} \mathrm{m})\end{array}$ & $\begin{array}{l}\text { Principial Export } \\
\text { ( } \% \text { of total) }\end{array}$ & & $\begin{array}{l}\text { Import } \\
\text { (fob) } \\
\text { (S m) }\end{array}$ & $\begin{array}{l}\text { Principial Import } \\
\text { ( } \% \text { of total) }\end{array}$ & \\
\hline Greece & 3.2 & $\begin{array}{l}\text { Agriculture, forestry \& } \\
\text { fishing } \\
\text { Mining, quarrying \& } \\
\text { manufacture } \\
\text { Electricity, gas \& water } \\
\text { Construction } \\
\text { Trade \& financial services } \\
\text { Transport \& communications }\end{array}$ & $\begin{array}{r}8.9 \\
\\
14.4 \\
2.2 \\
7.5 \\
19.5 \\
6.5\end{array}$ & 11,688 & $\begin{array}{l}\text { Manufactures } \\
\text { Food \& beverages } \\
\text { Petroleum products } \\
\text { Raw materials \& } \\
\text { serni-finished goods } \\
\text { Minerals } \\
\text { Tobacco }\end{array}$ & $\begin{array}{r}2,892 \\
1,033 \\
601 \\
\\
259 \\
229 \\
181\end{array}$ & 26,386 & $\begin{array}{l}\text { Manufactured consumer goods } \\
\text { Capital goods } \\
\text { Food } \\
\text { Crude oil } \\
\text { Chemicals } \\
\text { Iron \& steel }\end{array}$ & $\begin{array}{r}9,391 \\
5,643 \\
3,138 \\
2,128 \\
1,021 \\
704\end{array}$ \\
\hline Moldova & 1.3 & $\begin{array}{l}\text { Agriculture \& forestry } \\
\text { Manufacturing } \\
\text { Construction } \\
\text { Services }\end{array}$ & $\begin{array}{r}32.2 \\
28.6 \\
\\
4.6 \\
33.8\end{array}$ & 890 & $\begin{array}{l}\text { Food products, beverages \& } \\
\text { tobacco } \\
\text { Vegetable products } \\
\text { Live animals \& animal } \\
\text { products } \\
\text { Textiles } \\
\text { Machines, electronic devices \& } \\
\text { equipm. }\end{array}$ & $\begin{array}{c}54.8 \\
8.6 \\
\\
8.6 \\
6.6 \\
\\
5.2\end{array}$ & 1,235 & $\begin{array}{l}\text { Mineral products \& fuel } \\
\text { Machines, electronic } \\
\text { devices \& equipm. } \\
\text { Chemicals } \\
\text { Textiles } \\
\text { Metals \& metal products }\end{array}$ & $\begin{array}{r}12.9 \\
9.6 \\
5.3 \\
4.5\end{array}$ \\
\hline Romaniz & 4.1 & $\begin{array}{l}\text { Agriculture \& forestry } \\
\text { Industry } \\
\text { Construction } \\
\text { Services }\end{array}$ & $\begin{array}{r}18.8 \\
35.6 \\
5.4 \\
33.9 \\
\end{array}$ & 8.4 & $\begin{array}{l}\text { Textiles \& footwear } \\
\text { Basic metals \& products } \\
\text { Machinery \& equipment } \\
\text { Chemical products }\end{array}$ & $\begin{array}{r}23.0 \\
18.5 \\
8.7 \\
6.6 \\
\end{array}$ & 10.4 & $\begin{array}{l}\text { Machinery \& equipment } \\
\text { Fuels \& minerals } \\
\text { Textiles \& products } \\
\text { Chemical products }\end{array}$ & $\begin{array}{r}23.0 \\
18.9 \\
13.9 \\
8.3 \\
\end{array}$ \\
\hline Russia & 0.8 & $\begin{array}{l}\text { Agriculture } \\
\text { Industry } \\
\text { Services }\end{array}$ & $\begin{array}{r}6.5 \\
35.3 \\
58.2\end{array}$ & 88.9 & $\begin{array}{l}\text { Fuels \& energy } \\
\text { Metals } \\
\text { Machinery \& equipment } \\
\text { Chemicals }\end{array}$ & $\begin{array}{c}47.4 \\
20.8 \\
10.1 \\
8.2\end{array}$ & 71.3 & $\begin{array}{l}\text { Machinery \& equipment } \\
\text { Food \& agriculture } \\
\text { raw materials } \\
\text { Chemicals } \\
\text { Metals }\end{array}$ & $\begin{array}{r}34.9 \\
\\
26.1 \\
14.8 \\
6.9 \\
\end{array}$ \\
\hline Turkey & 5 & $\begin{array}{l}\text { Agriculture } \\
\text { Industry } \\
\text { Services }\end{array}$ & $\begin{array}{l}14.1 \\
28.6 \\
57.3\end{array}$ & 26.0 & $\begin{array}{l}\text { Agriculture \& live stock } \\
\text { Mining and Quarrying } \\
\text { Industrial Goods }\end{array}$ & $\begin{array}{r}10.7 \\
1.9 \\
87.4\end{array}$ & 46.7 & $\begin{array}{l}\text { Agriculture \& live stock } \\
\text { Mining and quarrying } \\
\text { Industrial goods }\end{array}$ & $\begin{array}{r}6.9 \\
9.7 \\
83.4\end{array}$ \\
\hline Ukraine & -3.2 & $\begin{array}{l}\text { Agriculture \& forestry } \\
\text { Industry } \\
\text { Trade \& services }\end{array}$ & $\begin{array}{l}17.8 \\
44.8 \\
37.4\end{array}$ & 15,418 & $\begin{array}{l}\text { Ferrous \& non-ferrous metals } \\
\text { Food \& agriculture goods } \\
\text { Chernicals } \\
\text { Machinery \& equipment }\end{array}$ & $\begin{array}{r}41.5 \\
14.0 \\
10.6 \\
9.6\end{array}$ & 19,623 & $\begin{array}{l}\text { Fuel, oil \& refining products } \\
\text { Natural gas } \\
\text { Machinery \& equipment } \\
\text { Chemicals } \\
\text { Foods \& agriculture goods }\end{array}$ & $\begin{array}{r}45.6 \\
29.1 \\
11.4 \\
7.3 \\
5.1 \\
\end{array}$ \\
\hline
\end{tabular}

1 Russia (1998); 2 Armenia, Azerbaijan, Georgia, Greece and Russia (merchandise export FOB); 3 Azerbaijan, Bulgaria and Greece (\$ m); 4 Azerbaijan, Georgia and Greece (merchandise export CIF); 5 Azerbaijan, Bulgaria and Greece (\$m)

Source: All data based on EIU reports $1^{\text {st }}$ quarter 1999 except (Bulgaria and Romania $4^{\text {th }}$ quarter 1998) and Turkey State Institute of Statistics. 
It will be some time yet before real stability will be achieved in those BSEC states which are former Soviet republics. The process may take at least a decade or more. Most BSEC economies remain incompatible with one another. Prior to the collapse of the Soviet Union, the centrally planned socialist economies organised their trade and production through the Council for Mutual Economic Aid (COMECON). Trade was organised on a non-competitive, interdependent basis. This habit has allowed a consensus to be achieved amongst former COMECON states on the transition to a market economy might be achieved, emphasising the importance of macroeconomic stability, increased competition, improved levels of private ownership and a better understanding of the role of the state. Greece and Turkey are much further down this road than other BSEC states yet both those countries remain in the development stage.

\section{b) Legislation on Trade and Finance}

BSEC states suffer from a wide gap between commercial and financial regulation. The former socialist republics joined the BSEC with commercial and financial laws which were completely unsuited to the market economy. A lack of adequate legal infrastructure continues to hold back the development of these countries..$^{13}$ The problems are myriad, as institutions remain uncertain of their role. The banking, insurance and financial services industries are in their infancy and there is a great need for foreign investment capital due to low savings rates of such countries. The BSEC hopes that the Black Sea Trade and Development Bank will be able to provide funds and expertise to bridge this via the World Bank and the EBRD. Western capital, however, is reluctant to enter much of the BSEC as long as regional instability remains. This is doubly so in the wake of the recent global financial crisis.

\section{c) Economic Information and Statistical Data}

As in so many other aspects of economic life in BSEC states, the quality and availability of economic statistics is poor. This stems partly from the poverty of many BSEC administrations and partly from the hangover of sloppy data collection methods from the Soviet era. For example, a reliable inventory of economic assets in the BSEC has yet to be compiled, although an agency has been created in an attempt to deal with this problem - the BSEC Co-ordination Centre for the Exchange of Statistical Data and Economic Information. ${ }^{14}$

\section{d) Transportation and Communications Infrastructure}

If the BSEC is to expand and develop, a modern transport and communications infrastructure is essential. The provision of such facilities is a massive undertaking and can only be achieved, according to the Transport and Communication Working Group of the BSEC, with the use of international finance. Some of the leading 
projects in this field include; trans-Balkan transport corridors linking east and west and north and south; linking of the Caucasus with Europe's road and rail network; the improvement of national road and rail networks in each BSEC state; increasing port capacity in Albania, Bulgaria, Romania, Georgia and Russia; construction of new ports and a road and rail "ring" around the Black Sea; improved transport links between Russia and Europe; and roll-on roll-off ferry links between Varna-Poti, Varna-Samsun, Constanze-Poti and Constanze-Samsun. ${ }^{15}$

These projects, with all that they entail in terms of border management and the elimination of restrictions on trade and movement, represent an ambitious attempt to improve co-ordination between Black Sea states.

BSEC states are also in desperate need of investment in telecommunications. Increasing demand in this sector places an ever greater burden of telephone networks that are already creaking under the strain. The Submarine Fibre-optic system (ITUR), linking Italy with Turkey, Ukraine and Russia, runs for $3.500 \mathrm{~km}$ and is estimated to have cost $\$ 170 \mathrm{~m}$. Another ambitious telecommunications project (KAFOS) aims to connect Varna, Mangalia and Istanbul over a distance of $600 \mathrm{~km}$. Moldova will also be included. A telecoms project in the eastern Black Sea (DOKAP) aims to connect Turkey with Georgia and Azerbaijan. That project, which is estimated to have cost $\$ 15.3 \mathrm{~m}$, involves digital microwaves and may be extended to the Caspian states. ${ }^{16}$

\section{e) Protection of the Environment}

It is not an exaggeration to say that ecological degradation threatens the ecosystem of the Black Sea. With an area of $420.300 \mathrm{sq} . \mathrm{km}$, it is one of the most important marine environments in the world. The millions of tonnes of solid and liquid waste, pumped each year into the Black Sea, has become a serious problem and the BSEC is looking at ways of alleviating the danger posed to countries with coastlines on the Black Sea. As many BSEC states begin industrialising on the western model, it will become increasingly important that environmentally friendly plant and techniques are introduced from the planning stage. The rivers which run into the Black Sea introduce enormous quantities of pollution every year. The Danube contributes $85 \%$ of the water flowing each year into the Black Sea, carrying with it pollutants from Germany, Austria, Hungary and Romania. Even waste from northern Europe is now finding its way into the Danube as a result of the Mainz-Danube canal. The BSEC is considering using a model based on EU environmental law in an effort to tackle the problem. Legislation is not enough, however, and clear co-operation between states in this sensitive area is essential. The economic development of the Black Sea region and its ecological well-being are inextricably linked. 
There is a further threat from nuclear pollution. According to a recent report prepared by a Turkish specialist, Professor M. Berküm, there are 20 nuclear power stations bordering the northern Black Sea, many of them neglected and unsafe. Professor Berküm claims that, without measures to improve the safety of these stations, the Black Sea may become dangerously radioactive within the next 20 years. If the nuclear threat is to be properly managed, a high level of co-operation is necessary along with a great deal of investment. The issue of radioactive pollution of the Black Sea is complicated not only by the meagre resources of the nations which border it but also by problems associated with persuading "upstream" states in Central and Eastern Europe to control their discharges into the Danube.

Co-operation is necessary between the BSEC, the EU and other, independent states. Legal and institutional arrangements matter less than common programmes, the exchange of ideas and states' sympathy for each others' problems and ideas. The economy and ecology of the entire region are inextricable. ${ }^{17}$

The Agreement was signed with a view to achieving progress in the protection of the Black Sea's marine environment and the conservation of its natural resources. According to the Agreement, states with Black Sea costlines agree to adopt common rules and regulations concerning the management of poisonous waste. ${ }^{18}$ Financial resources will be required to implement the Agreement. In the CIS alone, modernisation of some 60 nuclear power stations will require an investment of $\$ 40 b n .{ }^{19}$ The BSEC must work with the UN Development Programme, the UN Environmental Programme and the Global Environmental Facility. These three agencies provide financial aid for environmental projects. Despite these measures, however, controlling Black Sea pollution will remain a difficult task. The BSEC lacks legislative power to impose environmental solutions upon its neighbours. 20

Black Sea fisheries, a mainstay of many Black Sea economies, are a good example of how pollution can be economically damaging. The Black Sea supports a major fisheries sector with a total annual catch of more than two million tonnes. There has been a drastic decline in total catches and productivity due to pollution. One estimate puts the total number of potential job losses in the Black Sea fisheries sector at 150.000 . The fisheries problem also illustrates how little real co-operation there is between states in this area, despite the existence of the Black Sea Fisheries Convention. ${ }^{21}$

\section{f) Energy and Oil Pipeline Projects}

The BSEC region is rich in energy resources and provides enormous opportunities for their exploitation. The region enjoys $40 \%$ of the world's gas reserves, $15 \%$ of world oil, and $31 \%$ of the world's coal. The region also produces $15 \%$ of the world's electricity although the region produces a surplus of electricity, the 
surplus is not adequately distributed. Turkey, for example, suffers from a power shortage. This imbalance must be corrected by improved electrical infrastructure. Power production and distribution is a crucial area of co-operation for BSEC states. Energy consumption in the region has increased, on average, by $16 \%$ per annum since 1992 and is forecast to increase by between 20 and $25 \%$ per annum between 2000 and 2010.22

BSEC members may establish co-operation in the energy sector as follows:23

Exploitation of energy resources. Multi-national companies dominate in this field. The principal projects are the transportation of Caspian oil, the exploration for oil in the Black Sea itself and the development of energy resources in Russia.

Development of the flow of energy resources within the region. The construction of new pipelines and power transmission infrastructure is essential if the imbalance of energy distribution in the region is to be rectified. Major energy infrastructure projects are already underway, increasing pipeline capacity from Russia and the Caspian region.

Development of power generation capacity. Power generation in the region is, by and large, old-fashioned and inefficient. Construction of new power generation capacity is a prerequisite of regional economic development. The energy sector is an excellent example of how co-operation between BSEC states is necessary if common projects are to be realised successfully. The problem of how to transport oil from Azerbaijan to world markets is a good example of just such a common project.

\section{Possible Routes for the Transportation of Azeri Oil}

The Azeri economy is dependent upon oil resources and its economy is, therefore, hungry for financial aid to assist it in developing this important resource. Transporting oil from Azerbaijan is, however, problematic. There are various possible routes for an oil pipeline out of Azerbaijan. They may be summarised as follows (see Figure IV)

\section{a) Baku-Ceyhan via Armenia}

This route passes from Azerbaijan through Armenia and Turkey to the port of Ceyhan on Turkey's Mediterranean coast (Number 1). This is the preferred route of Turkey and the USA but faces difficulties because of the Azeri-Armenian conflict and Russia's reluctance to see a diminution of its power in the region. Russia would prefer to see the oil going through its port at Novorossisk on the Black Sea and then through the Bosphorus and Dardanelles Straits on tankers. 
Figure IV: Possible Routes for the Transportation of Azeri Oil

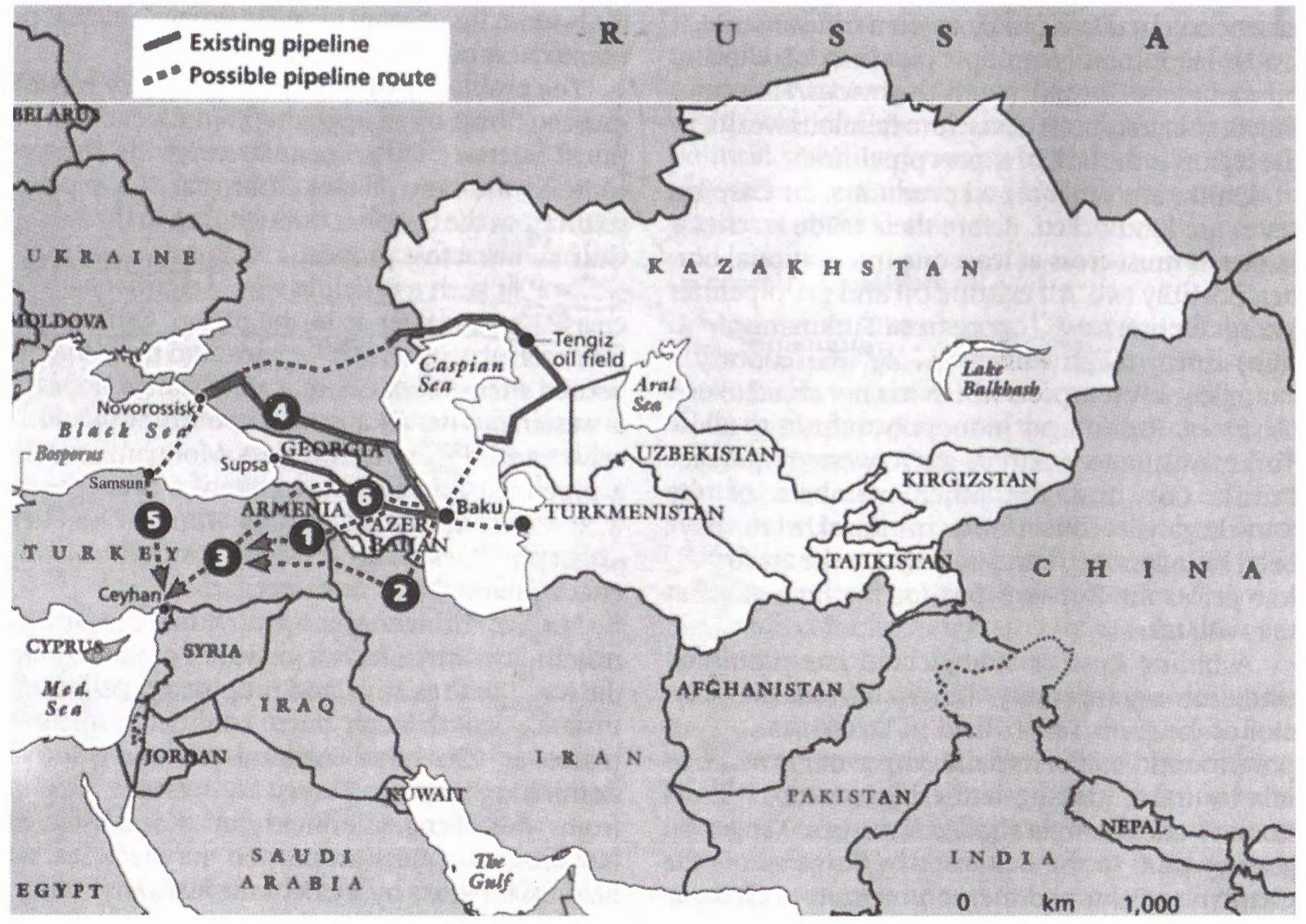




\section{b) Baku-Ceyhan via Iran}

Islamic fundamentalism in Iran makes this route unpopular with the USA. To pass a pipeline through Iran would make it vulnerable in a crisis and would enhance Iranian power in the region (Number 2).

\section{c) Baku-Ceyhan via Georgia}

This route would go beneath the Black Sea. It is less politically fraught than some others but Georgia is unstable and the realisation of the project may prove more expensive than the other available routes $(\$ 2.9 \mathrm{bn}$ ) (Number 3). Kazakh oil and Turkmen gas could feed into western route via trans-Caspian pipelines.

\section{d) Baku-Novorossisk}

This route would necessitate moving oil by tanker through the Bosphorus. Russia prefers this route for obvious reasons ${ }^{24}$ but Turkey opposes it. Russia's recent turmoil adds weight to Turkish concerns that such a route would give Russia a stranglehold on the region's oil resources. Turkey also fears that to move so much oil through the Bosphorus and Dardanelles is to court environmental disaster. The USA, however, does not want to see Russia completely excluded from participation in such projects. The eventual solution may, in the end, be a combination of two or more of these options, with a certain quantity of Caspian oil passing through Novorossisk (number 4). This view is shared by other BSEC members anxious not to antagonise their Russian neighbours. Economic ties with Russia remain strong in the Black Sea region.

Turkey, however, has a legitimate concern about the Baku-Novorossisk route. Moving too much oil through the Bosphorus and the Dardanelles increases the risk of an environmental catastrophe in that area. Millions of people live in Istanbul. A tanker accident in the straits could kill thousands and ruin countless livelihoods. There is a precedent. In May 1994, the Cypriot registered tanker, Nassia, collided with a coaster and caught fire in the Straits. ${ }^{25}$ The accident brought about a change in Turkish policy on the Straits. Under the Montreaux Convention of 1936, international merchant vessels are guaranteed access to the Straits. It is, therefor, difficult for Turkey to impose regulations on passing vessels which are too onerous. Consequently, of the 40.000 vessels which traverse the Straits each year, fewer than half of them take a pilot on board. ${ }^{26}$

Oil cargoes are, naturally, Turkey's main concern. If the Baku-Novorossisk route were chosen, it is estimated that 80 million tonnes of crude oil would pass through the Bosphorus and Dardanelles each year, compared with 5 million tonnes at present. Since July 1994, the Turkish government has imposed tighter rules on vessels in excess of 150 metre in length - a move clearly aimed at tanker traffic. These rules do 
not, of course, prohibit tanker traffic and are consequently of limited benefit. Such rules may reduce the risk of a serious accident but that risk cannot be eliminated entirely. The $31-\mathrm{km}$-long Bosphorus is a dangerous waterway with strong, erratic currents and 12 narrow turns., ${ }^{27}$ To make matters worse, traffic through the Straits has increased dramatically since the fall of the Soviet Union due, in part, to the Bosphorus being the fastest and cheapest route for Eastern European goods travelling to world markets, some goods passing into the Black Sea even from the Mainz-Danube canal system, which links the Baltic with the Black Sea.

The Turkish government has, consequently, put forward an alternative proposal. This involves pumping oil to Novorossisk, whereupon it is put on to tankers and taken to Samsun, from where it is piped to Ceyhan (Number 5). This option has failed to find favour with Western governments because, if it were the sole route, it would hand Russia too much power over supplies. It would also be a round about and expensive means of transporting oil and gas.

The Greeks, too, have made a proposal. They suggest pumping oil to Novorossisk, then moving it by tanker the Bulgarian port of Burgas and then across the Balkans by a $320 \mathrm{~km}$ pipeline to the Greek port of Alexandroupolis on the Aegean Sea, to be put, once again, onto tankers for the onward journey to world markets. A further option, they say, would be to extend the existing pipeline from Novorossisk down through Moldova, Romania and Bulgaria into Greece. Neither of these options is attractive to the West for obvious political and commercial reasons.

Given the large choice of routes and the myriad competing interests, it is hard to predict which route will succeed. Given that the USA favours the western option, a pipeline at least as far as Supsa in Georgia seems the most likely outcome. A pipeline from an off-shore Azeri field to Supsa "early oil" (from new investment) became operable shot time ago (Number 6). What happens to the oil from there depends greatly on the solution to the problem of the Bosphorus and Dardanelles Straits.

Oil that is already being pumped out of Azeri fields is currently being pumped through existing pipelines between Baku and Novorossisk and Baku and Supsa. At present, the Azerbaijan International Operating Company $(\mathrm{AIOC})^{28}$, a consortium representing the World's major oil companies, is pumping its oil north to the Russian Black Sea port of Novorossisk via a 20-years-old pipeline of limited capacity that crosses the politically volatile North Caucasus, including Chechnya and Dagestan, rife with ethnic tensions.

In January 1999, AlOC inaugurated a second small pipeline, running 820 kilometres west to the Georgian Black Sea port of Supsa. An upgrade of this pipeline is the cheapest option, costing around $\$ 600 \mathrm{~m}$, with a capacity of 100,000 barrels a day. This would only be sufficient for a short time, however. 
New [main export] pipelines would be required in the long-term as more Caspian oil and gas comes on stream.

The USA and Turkey favour the Baku-Ceyhan route but it is expensive. The only way to ameliorate that expense is by giving access to the pipeline to as many Caspian producers as possible. Kazakh oil, as well as that of Azerbaijan, must flow through such a pipeline if it is to become economically viable. Consequently, the USA has put great effort into persuading the Kazakhs to accept a western route. The USA has also leant heavily on Turkmenistan to shelve its plans for a pipeline through Iran. If the West insists on the Baku-Ceyhan route, it may find itself having to subsidise the project in the interests of strategic efficacy. ${ }^{29}$

Support for Turkey in the US seems assured. As Ross Wilson, special advisor to the State Department, explained at a conference held in Washington in March 1998 on Oil and Gas in the Caspian Region, support for Turkey is one of the three most important US policy objectives in the region, the other two being containment of Iran and prevention of a reassertion of Russian hegemony in the region. Turkey is crucial to US interests because of its unique geographical position and its status as a secular, Muslim state. Nevertheless, Mr. Wilson warned, US oil companies are private bodies which must not keep Russia and Iran completely out of the running due to the political risks of doing business in the region. ${ }^{30}$

Turkey, then, should not regard the Baku-Ceyhan route as a 'done deal'. The route does, of course, benefit Turkey in a number of important ways, namely:

- It would enable Turkey to buy oil more cheaply on world markets.

- It would benefit from the transit revenues arisig from the use of the pipeline.

- It would enable Turkey to build an oil industry around the Mediterranean port of Ceyhan.

- Turkey could strengthen its influence in the Caucasus and Central Asia.

- As a NATO member and oil consumer (rather than producer), fewer conflicts of interest might arise over the use of the pipeline.

Strategically, the Baku-Ceyhan route has no serious competition. Of course, it is no coincidence that the USA is now trying to engage the Iranian government in dialogue to 'break the wall of mistrust', whilst waiving sanctions against EU countries who invest there. It is in the USA's interests to support the moderate forces in Iranian politics. ${ }^{31}$ 
Iran has recently been engaged in negotiations to develop off-shore fields in the Gulf. Iran does not have the technology to exploit such resources by itself. However, the terms offered by the Iranian government were not attractive and were insufficient to compensate interested companies who might, if they went ahead, fall foul of the Iran-Libya Sanctions Act. ${ }^{32}$

It is clear, then, that the United States wants to see the frustration of Iran's pipeline ambitions in the Caspian region. US policy in this respect clearly has an impact upon the BSEC. However, Iran's geographical position and established oil infrastructure make it a big draw for the major oil companies. The prospect of integrating the Iranian and Caspian oil industries is appealing indeed to the major oil companies. In June 1998 , Iran issued a tender for a $\$ 400 \mathrm{~m}$ pipeline to transport Caspian oil to refineries in Terhan and Tabriz. The capacity of these refineries is up to 315.000 barrels of oil per day. Those companies, such as BP and Shell, with extensive US interests, however, are reluctant to become too involved. 33

If world oil consumption increases as forecast (by $3.6 \mathrm{~b}$ tonnes to $5.2 \mathrm{bn}$ per annum by 2010), not just one but two new pipeline projects will be required to transport Caspian oil. However, with world oil prices at an all time low in real terms, and with a possible global recession looming, oil companies will need more persuading to make such large investments in the near future. Economic factors are currently in conjunction with political instability in the region (though property rights seem, for the time being, secure), and this is a powerful disincentive for oil companies to invest shareholders' money.

There is another dark cloud on the horizon which is often overlooked. Until 1991, the Caspian Sea was shared by the Soviet Union and Iran under the terms of the Treaty of Moscow, 1921. Since the break-up of the Soviet Union, dispute has arisen as to who actually owns the seabed beneath which lies the oil. Russia and Iran, with little oil directly off their coasts, content that the seabed should be the joint property of all the littoral states. Kazakhstan and Azerbaijan, with the largest oilfields right on their doorsteps, have most to lose from such an arrangement and would prefer a different division. Azerbaijan has been the main proponent of a division of the Caspian along national lines. The Iranians would lose most from the Azeri plan because of the paucity of fields off their shores. Russia would not be so badly off because it already possesses substantial fields on its Caspian shores, but Russia gibs at losing so much potential wealth to the newly independent states. ${ }^{34}$

Russia has much to gain by compromising on the Caspian issue, however. Firstly, Russia needs to foster relations with the former Soviet states, Kazakhstan in particular. This is especially so as Russia's southern borders become less secure as instability in Asia worsens. Secondly, a Russian compromise in the Caspian would 
be an acceptance of reality. The Azeris have been leasing fields for some time. Thirdly, as long as the Russian foreign ministry bleats about the Caspian, Russian oil companies continue to lose out on commercially valuable oil deals. A Caspian treaty, if it comes, would be a valuable catalyst for stability in the region as a whole. Much, however, depends on Iran.35

To conclude, it is the lack of adequate export infrastructure that holds back the oil projects of the Caspian and, in turn, the solution to the energy problems of the BSEC states. However, as great as the imperative for energy security in the region is, this aim must be balanced by economic feasibility. The capacity of the AIOC 'early oil' routes is very limited and major new construction is essential. If the Baku-Ceyhan route (favoured by the US, Turkey and Azerbaijan) is to succeed, financial sweeteners in the form of fiscal concessions and subsidies will have to be provided. The diplomatic fight over whether to build a pipeline to Ceyhan or to Novorossisk will become a litmus test for Russian political and commercial ambitions in the Caspian area. The latest instability in Russia cannot make the outcome of this issue any easier to predict.

The Caspian pipeline issue has become a policy priority of the United States. Securing the West's oil supplies, particularly in view of the increased instability across the whole of Asia, has become a major headache for the western, industrialised countries. The main aim must be to secure oil supplies without excluding the region's main powers. This must involve fostering co-operation and infra-structural integration between the region's main powers - Turkey and Russia. Such projects must:

- reduce the effect of political factors on the decision making processes for pipeline routes;

- break Russian dominance over the energy resources of the region without isolating it completely; and

- bring sufficient commercial benefits to the region so as to provide an incentive to maintain political stability.

\section{BSEC-EU Relations}

The BSEC is intersted to improve its economic and commercial relations not just with the EU but other trading blocs too. Indeed, the BSEC declaration firms, "the intention to develop economic co-operation as a contribution to the CSCE process, to the establishment of a Europe-wide economic area, as well as to the achievement of a higher degree of integration of the participating States into the world economy".

Naturally, however, the EU is the main focus of the BSEC's western members. It is certainly true that prospective EU members need not join the EU with single, 
quantum leap but may benefit initially from differing levels of economic integration with the EU. Full membership remains a political, rather than an economic, goal. Indeed, the principal motivating force behind BSEC members' desires for EU membership is not the prospect of economic gain but a need for political and military security.

\section{How ready are BSEC states for EU membership?}

There are four basis criteria which determine a country's suitability for cooperation with the EU at any given level. ${ }^{36}$ Firstly, location is important because prospective members of the EU should, ideally, have contiguous borders with other EU states. Secondly, a prospective member's economic system must be compatible with that of the EU. Only those countries with a consistent record of commitment to the market economy will be considered for membership. Thirdly, a country's level of economic development must be relatively advanced. A large gap in development might make meaningful integration impossible due to the need for financial assistance and barriers being erected to goodsproduced at relatively lower costs in that country. Less developed members might also lose trade and aid privileges as a consequence of membership. Finally, the level of political stability and the nature of a prospective member's political system are crucial factors. EU membership demands the harmonisation of institutions and policies. Only established democracies will be considered for for membership. There must be a reasonable prospect that any member will be able to maintain its democratic principles and respect the human rights of its citizens.

With the notable exceptions of Greece and Turkey, the BSEC states are all former socialist states undergoing the difficult tarnsition to market economies. They may be separated broadly into four groups. This separation is driven by "readiness factors" which emphasise similarities between states rather than differences. ${ }^{37}$

Group 1: Greece and Turkey. Greece is the only BSEC member which is also a member of the EU. Turkey's close association with the West goes back more than 150 years. It was instituted as a means of bolstering the process of Westernisation and overcoming social and economic backwardness and helping to establish Western orientated human rights. Under the terms of the Ankara Agreement of 1963, Turkey entered a customs union with the EU in January 1996. This customs union created a mostly tariff-free trade area between Turkey and the EU in industrial, though not agricultural, goods. Turkey has since adopted the Common External Tariff. The EU is Turkey's most important trading partner, accounting for half of Turkey's trade, and the volume of trade between Turkey and the EU has been increasing continually since 1963. Moreover, around 2,5m Turks live and work in the EU (mostly Germany), remitting some $\$ 3 \mathrm{bn}$ to Turkey each year. This revenue is an important source of 
foreign currency for Turkey, enabling it to import more than its exports would otherwise allow. EU citizens also spend an increasing number of their holidays in Turkey, further strengthening Turkey's current account.

Group 2: Albania, Bulgaria, Romania, Moldova and Ukrain. A free trade area has been formed, through the conclusion of a European agreement, between the EU, Bulgaria and Romania.38 Customs duties and quotes have thus been abolished. Moreover, Romania and Bulgaria have been included in a list of twelve countries as candidates for EU membership. The EU has signed a "partnership and co-operation" agreement with Moldova and Ukraine (and also Russia). "Most Favoured Nation" (MFN) status has been granted to each of these countries. According to the agreement, Moldova and Ukraine are within the "General Preferences System" (GPS), which means that goods imported from these countries will not be subject to the "Common Customs Tariff". Quantitative resrictions to imports from these countries into the have been abolished to a great extent. Albania has also been granted MFN status and has been included in the GPS.

Group 3: Armenia, Azerbaijan and Georgia. These countries are affected by internal, ethnic conflict. Their geographical isolation from Western Europe means that they are unlikely to be considered for EU membership.

Group 4: Russia. Russia is a special case and may be considered to be in a group all of its own. Russia is too large and its interests too wide for it to be considered alongside any other BSEC member. Neither is Russia ever likely to be a member of the EU. Russia has experienced enormous difficulty transforming itself into a liberal, market economy with a stable, pluralist political sytem. It is also somewhat preoccupied by internal, ethnic conflict and still suffers from centralist tendencies. The recent financial and economic crisis there has put the entire reform process in grave peril.

To conclude, membership of the BSEC does not preclude either full EU membership or any other, similar relationship. Indeed, the BSEC may be regarded as a useful stepping stone towards that goal for many, though not all, of its members. Regional co-operation initiatives such a the BSEC complement the cause of panEuropean integration rather than damaging it.

The BSEC seeks neither to preclude nor prevent membership of the EU of its members. In the past, the BSEC positively facilitates and encourages it by aiming to improve the economic and political condition of its members. Neither does BSEC membership preclude its members being partners in other regional trading arrangements. The BSEC Declaration makes clear that, "their economic co-operation will be developed in a manner not contravening their obligations and not preventing the promotion of the relations of the Participating States with third parties, including 
international organisations as well as the EU and the co-operation with the regional initiatives".

The EU does not see the BSEC as arival organisation. Rather, the EU sees it as complimentary, fostering pan-European integration by providing the conditions in which its members may develop economically and politically with a view to eventual integration into the EU. This is also how most BSEC members view the arrangement. The BSEC, then, constitutes an important element of the European project, promoting the dissemination of Western European institutional know-how and standards - a prerequisite of entry into the EU. In this way, the BSEC can act as a catalyst for the transformation of its members into pluralist, market orientated democracies.

The BSEC may also have a wider purpose, that of enabling its members to make a smooth transition into a global political, economic and social system. Such a transition matters to the EU because it wants a stable BSEC, fully bound and integrated into the world community. The EU therefore helps the BSEC to identify common interests and to develop the policy tools to tackle them. The BSEC is therefore central to the EU's policy towards its Eastern neighbours and future cooperation with the EU must seek to institutionalise an effective political and economic dialogue.

The EU's policy towards the BSEC is 3-pronged:

a) The EU seeks to bolster the economic and social development of the BSEC by providing structural and political support. If the co-operative alliances of the region are to complement the EU's pan-European policy, the EU must involve itself in the socioeconomic development of the Black Sea region. Further, since the free movement of goods, services, labour and capital is important to the process of economic development in a liberal environment, the EU needs to help create the framework within which this might be achieved. The EU is well placed to provide this kind of support because of its domination of trade in the region and its stability to set an example for aspirant states who look up to the EU as a model. By fostering cooperation in trade, the EU may provide the impetus for and the framework within which, fiscal and financial institutions may develop. If the BSEC states are to benefit from liberalised trade, they must transform their laws and labour policies which, in turn, will foster economic and political stability.

b)The EU provides an example of how democracy can work to the advantage of those countries which genuinely adopt it. The sustainable democratisation of Eastern Europe is a principal policy goal for the EU. Without such development, stability will be undermined and economic development threatened. Pan-Europeanism cannot succeed without sustainable democracy. 
c) The third element of EU policy in the BSEC region is security. The political instability sand military might of some of the EU's Eastern neighboursis a cause of some concern for the EU (and, indeed, some BSEC members). The security of Europe's periphery is, perhaps, the EU's most important aim. Everything that the EU does in the BSEC area must, therefore, have this overall objective in mind. Part of this policy includes the fight against organised crime, drugs and armssmuggling. The effect of these illicit trades on the BSEC countries is very destabilising and constitutes a serious threat to the EU.

Since the BSEC is an integral and complimentary element of the pan,European project, the institutions of the EU must continue to contribute resource (political, intellectual and financial) to assist the BSEC in its efforts to become more efficient and economically successful. The success of the BSEC is surely in the interests of the EU.

Indeed, the European Commission already contributes to institutions affiliated to the BSEC, such as the Bank for Trade and Development, the International Centre for Black Sea Studies and the Black Sea Regional Energy Centre. The EU also contributes to Black Sea environmental projects through its PHARE and TAClS programmes. These contributions should be increased in value and widened in scope. Perhaps a special programme based on PHARE, TACIS and SYNERGY may be established specifically for the BSEC. The European Commission is in a unique position to provide BSEC states with technical assistance in areas such as customs standards and certification as well as a vast range of other areas of importance. The European Commission may, for example, request observer status at BSEC summits and conferences. As separate sections of the EU become more interested in the BSEC, a more focused approach to this issue may be adopted and a sectoral dialogue developed. Clearly, the EU has a surplus of capital and the BSEC a surplus of resources. These elements can surely be combined to the advantage of both.

\section{Conclusions}

The Black Sea project has the potential to change the economic and potential face of the Black Sea basin. It is a new organisation of developing countries struggling to cope with serious economic and political problems and difficult historical legacies. The BSEC is, in short, one of the means through which its members seek to develop politically and economically and through which its ex-socialist members aspire to be admitted to the community of advanced industrialised nations. This article's conclusions may be summarised under the following headings:

a) The BSEC's political and economic problems. The BSEC is constrained by its political and economic problems. Although these constraints seem daunting, the future may be brighter due to aceptance of the framework of a market economy 
combined with a large number of skilled workers in the region and an abudance of rich natural resources. It is certainly true, of course, that, in the short run, the impact of the BSEC's development will be limited. However, the importance of the BSEC in the short run is political, not economic. In particular, it brings round the same table neighbours who have, in the past, viewed each other with deep suspicion. The establishment of the BSEC's institutions (particularly the Parliamentary Assembly) is the first step to solving many of its members' political disputes and problems.

Only in the medium to long term will the BSEC be able to play an important economic role. With time, a free trade area may be introduced and differences in the levels of development of member states will be reduced through economic cooperation. Greece and Turkey are already free market economies, but the exsocialist BSEC members are not. As members of Comecon, they had adopted noncompetitive, inter-dependent trade positions. It is because such countries remain in a transition phase that it is difficult for them to intensify their foreign trade activities. In particular, they lack reliable time-series economic data (such as price indices). This makes it very difficult for investors to plan for the future - slowing the flow of foreign investment to the region.

Furthermore, the ex-socialist countries lack developed private sectors. This deficiency hinders market development and limits the scope for efficiency in resource allocation. This problem is, perhaps, best illustrated by the examples of Russia and Ukraine. Both have extensive industrial bases but they are hopelessly obsolete and uncompetitive. There is determined resistance to the reform of these industries in those countries. Even Greece and Turkey have their problems. Only with EU aid has Greece (an EU member since 1981) been able to develop as far as it has. Turkey, too, has serious political and economic problems, which it must face without the benefit of EU membership, though its customs union with the EU may begin to change that.

b) The BSEC as a means of promoting development. This is the principal aim of the BSEC, for without real and sustainable economic and political development, BSEC members will find it impossible to realise their collective aims and objectives. Firstly, the BSEC can provide technical assistance to potential investors in the region, providing for example, data on the economic and social aspects of the member countries. Secondly, it can also provide financial assistance for common projects among the member countries, as in, for example, the establishment of the BSEC Trade and Development Bank. Thirdly, the BSEC provides a useful conduit through which EU aid may flow. Such aid is crucial if BSEC members are to develop their social, political and legal infrastructure quickly. Fourthly, it may act as an agency for the promotion of more intensive trade relations with third countries such as those in the EU, the Americas and the Middle and Far East. Fifthly, the BSEC can help 
promote free trade in the region. Finally, the BSEC provides a forum at which member states (many of whom have serious and long-standing disputes with one another) may come around a table to discuss issues of mutual interest - a first step towards solving some of their more intractable problems.

c) The BSEC's relations with the EU. The BSEC is interested in the EU because each of its members (Greece and Russia excepted) aspire to full EU membership. The BSEC is a good platform from which such states may begin the process of political and economic development necessary to qualify as prospective EU members.

The EU is interested in the BSEC because it hopes that the BSEC will be able to bring stability and some measure of prosperity to the countries on and beyond its eastern boundary, through political and economic development. The instability of many BSEC members is a source of great concern to the EU, which fears mass migration to the West in the event of a serious international crisis in the region.

So then, while the BSEC needs the EU's aid and assistance, the EU needs to cultivate and foster its relations with the BSEC member states. Furthermore, as the EU's internal market reaches maturity (arguably, it has already done so) the vast potential market offered by the BSEC (some $325 \mathrm{~m}$ people) offers the EU huge economic opportunities.

d) The BSEC as a platform from which its members may apply to join the EU. Only one BSEC member (Greece) is already a full member of the EU. Turkey enjoys a customs union with the EU and closer economic and political ties than perhaps any other BSEC member. Almost every BSEC member state not already a full member of the EU aspires to become one, except, stet, Russia. Russia is too large and politically diverse to become a full member of the EU and, anyway, has a history which would make it difficult for its leaders to promote membership to its population.

To non-EU members, EU membership is seen as a panacea for their political and economic ills. Before such aspirations can be realised, however, such countries must first go a long way to ridding themselves of precisely those problems which they see EU membership as helping to cure.

The BSEC is not a supra-national organisation, nor was it founded as a potential competitor to the EU. Rather, it may act as a 'half-way house' from which its members may apply for EU membership once they have achieved the requisite level of political and economic development. It is, then, a complimentary organisation. That is why the founding document of the BSEC is in the way of a flexible declaration rather than a rigid agreement.

e) Turkey's role in the BSEC. Turkey is fully integrated into the world economy. It 
has close bilateral relations with many countries and multilateral relations within the framework of some international organisations. In addition to the BSEC, Turkey is a member of i) the Economic Co-operation Organisation (ECO) ${ }^{39}$, ii) the Organisatison of Islamic Conference $(\mathrm{ClO})^{40}$ and iii) the Developing 8 (D-8). ${ }^{41}$ Furthermore, Turkey also has been in a customs union with the EU since 1996 (see Table III). Standing at one of the world's crossroads (culturally, economically and politically), Turkey is uniquely placed to assist in the development of other BSEC members.

The BSEC project is important for Turkey not only because it increases trade volumes with its neighbours (see table IV) but also because Turkey hopes that its involvement with fellow BSEC members will foster a favourable image with the EU, thus accelerating its progress to full EU membership. If Turkey is able to play a leading role within the BSEC, then it will improve its influence in the region and further justify its eligibility for full EU membership in due course.

The transition process of ex-socialist member countries shows clearly that there are a number of opportunities for commercial and economic co-operation within the BSEC project. Firstly, implementing common projects, particularly in the telecommunications, transport, and energy sectors, would affect positively the economies of the member countries. For example, more than one pipeline is needed to transport Azeri oil to world markets. Turkey also attributes a great deal of importance to the construction of pipelines linking it to the Azeri oil resources, and then, to the oil and natural gas basin in other Turk republic around the Caspian Sea. A pipeline road, such as Baku-Ceyhan project, not only responds to Turkey's energy needs, but also ensures a steady supply of cheap energy and an important strategic role in the region. Such a pipeline would develop the chemical and petrochemical industries in Turkey. This project would also bring benefits to the economy of Azerbaijan. Such a pipeline would ensure a supply of foreign exchange which Azerbaijan needs for accelerating the transition process to a market economy, and then, for full integration into the world economy.

Turkey's geographical position furthers closer economic and commercial relations with BSEC members. In this regard, border and oftshore trade are important for Turkey not only because these can be an alternative to increase the volume of trade with its neighbours but also because Turkey hopes that such close economic and commercial relations would intensify contact among the peoples of Turkey and other BSEC countries around the Black Sea thus reversing the Cold War situation, in which there was little contact among the peoples of the region. Undoubtedly, this process would also contribute positively to an increase in business activity and the magnitute of tourism sector.

An important result of the Cold War was that Turkey's Black Sea region was less developed. The region depended on Mining (particularly coal in Zonguldak), and on agriculture (particularly tabacco, tea and nut). Migration from the region to other developed regions in Turkey is also relatively high. A close relationship across borders would also help encourage infrastructure investment on the Turkish Black Sea coast (particularly in the building of new ports and/or re-constructing existing ports). 
Table III: Turkey's Trade with Country Groups ( $\$$ '000)

\begin{tabular}{|l|l|r|r|r|r|r|}
\hline $\begin{array}{l}\text { Country } \\
\text { Groups }\end{array}$ & & \multicolumn{1}{|c|}{1994} & \multicolumn{1}{c|}{1995} & \multicolumn{1}{c|}{1996} & \multicolumn{1}{c|}{1997} & \multicolumn{1}{c|}{$\begin{array}{c}\text { Jan.Feb. } \\
1998\end{array}$} \\
\hline BSEC & Import & 2.166 .461 & 3.998 .112 & 3.944 .961 & 4.575 .972 & 721.003 \\
\hline & Export & 1.636 .534 & 2.425 .530 & 2.872 .583 & 3.716 .213 & 576.212 \\
\hline EC & Import & 10.915 .179 & 16.860 .584 & 23.138 .057 & 24.869 .690 & 3.508 .869 \\
\hline & Export & 8.635 .376 & 11.078 .005 & 11.548 .631 & 12.247 .710 & 2.046 .902 \\
\hline ECO & Import & 922.158 & 1.136 .784 & 1.196 .819 & 1.106 .928 & 168.521 \\
\hline & Export & 752.067 & 910.987 & 1.086 .486 & 1.286 .468 & 168.521 \\
\hline D-8 & Import & 1.099 .185 & 1.488 .681 & 1.597 .100 & 1.563 .222 & $*$ \\
\hline & Export & 675.021 & 755.988 & 905.705 & 874.829 & $*$ \\
\hline
\end{tabular}

Source: State Statistics Institute, Foreign Trade Statistics

\section{Table IV: Turkey's Trade with the BSEC Countries ( $\$$ '000)}

\begin{tabular}{|c|c|c|c|c|c|c|}
\hline Countries & & 1994 & 1995 & 1996 & 1997 & $\begin{array}{c}\text { Jan.-Oct. } \\
1998\end{array}$ \\
\hline \multirow[t]{2}{*}{ Albania } & Import & 1.527 & 1.274 & 9.192 & 3.379 & * \\
\hline & Export & 59.317 & 56.942 & 53.871 & 41.102 & * \\
\hline \multirow[t]{2}{*}{ Armenia } & Import & - & - & - & - & * \\
\hline & Export & - & - & $\overline{-}$ & - & * \\
\hline \multirow[t]{2}{*}{ Azerbaijan } & Import & 8.883 & 21.777 & 39.165 & 58.269 & 43.000 \\
\hline & Export & 132.124 & 161.345 & 239.903 & 319.702 & 263.000 \\
\hline \multirow[t]{2}{*}{ Bulgaria } & Import & 195.508 & 402.029 & 362.771 & 408.852 & 285.000 \\
\hline & Export & 133.663 & 183.176 & 156.906 & 175.887 & 169.000 \\
\hline \multirow[t]{2}{*}{ Georgia } & Import & 25.652 & 50.157 & 110.319 & 173.510 & 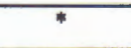 \\
\hline & Export & 67.071 & 68.126 & 77.824 & 107.576 & * \\
\hline \multirow[t]{2}{*}{ Greece } & Import & 105.067 & 200.673 & 284.959 & 430.780 & 284.000 \\
\hline & Export & 168.854 & 209.952 & 236.464 & 298.237 & 289.000 \\
\hline \multirow[t]{2}{*}{ Moldova } & Import & 20.453 & 15.616 & 14.468 & 15.077 & * \\
\hline & Export & 3.628 & 7.270 & 14.397 & 21.334 & * \\
\hline \multirow[t]{2}{*}{ Romania } & Import & 228.911 & 367.870 & 441.290 & 394.087 & 281.000 \\
\hline & Export & 175.342 & 301.960 & 314.045 & 358.783 & 355.000 \\
\hline \multirow[t]{2}{*}{ Russia } & Import & 1.045 .389 & 2.082 .376 & 1.921 .139 & 2.174 .258 & 1.768 .000 \\
\hline & Export & 820.250 & 1.238 .225 & 1.511 .634 & 2.056 .547 & 1.141 .000 \\
\hline \multirow[t]{2}{*}{ Ukraine } & Import & 535.071 & 856.340 & 761.658 & 917.760 & 849.000 \\
\hline & Export & 76.285 & 198.534 & 267.539 & 337.045 & 221.000 \\
\hline \multirow[t]{2}{*}{ TOTAL } & Import & 2.166 .461 & 3.998 .112 & 3.944 .961 & 4.575 .972 & 3.510 .000 \\
\hline & Export & 1.636 .534 & 2.425 .530 & 2.872 .583 & 3.716 .213 & 2.438 .000 \\
\hline
\end{tabular}

Source: State Statistics Institute, Foreign Trade Statistics 


\section{Appendix 1 \\ Declaration on the Black Sea Economic Co-operation}

1- Taking into account the profound and rapid changes in Europe and the determination of the peoples of the continent to shape a new era of peace and security on the basis of the principles laid down in the Helsinki Final Act and the follow-up CSCE documents and particularly in the Charter of Paris for a new Europe,

2- Recognizing that a prosperous and united Europe will evolve on shared values such as democracy based on human rights and fundamental freedoms, prosperity through economic liberty and social justice, and equal security for all our countries,

3- Taking into consideration the potential of the participating States and the opportunities for enhancing the mutually advantageous economic co-operation arising from their geographic proximity and from the reform process and structural adjustments,

4- Conscious of the importnace of the environmental problems opf the Black Sea for the well-being of their peoples and recognizing that it is vital to ensure the environmental sustainability of their economic development,

5- Confirm the intention to develop economic co-operation as a contribution to the CSCE process, to the establishment of a Europe-wide economic area, as well as to the achievement of a higher degree of integration of the participating States into the world economy,

6- Share the common objectives to achieve the further development and diversification of both bilateral and multilateral co-operation among them as well as with other intersted countries, to foster their economic, technological and social progress, and to encourage free enterprise,

7- Agree that their economic co-operation will be developed in a manner not conravening their obligations and not preventing the promotion of the relations of the participating States with third parties, including international organizations as well as the $\mathrm{EC}$ and the co-operation within the regional initiatives,

8- Aim to 'ensure that the Black Sea becomes a sea of peace, stability and prosperity, thriving to promote friendly and good neighbourly relations,

9- Declare that the economic co-operation among the participating States will be developed on the basis of the principles of the Helsinki Final Act and the decisions in the subsequent CSCE documents, as well as of the other universally recognized principles of international law, 
10- Agree that the economic co-operation will be promoted gradually and,- while determining the priorities in this process, they will take into account the specific economic conditions, intersts and concerns of the countries involved, and particularly the problems of the countries in transition to market economy,

11- Affirm that the whole economic co-operation among their countries is open for the participation of other interested States recognizing the provisions of this Document. As regard projects of common interest, individual countries, their economic and financial institutions could be involved in their realization,

12- Decide to develop comprehensive multilateral and bilateral Black Sea economic co-operation, covering the various fields of activity as specified below,

13- Affirming their determination to make best use of all possibilities and opportunities for expanding and multiplying their co-operation in the fields of economics, including trade and industrial co-operation, od science and technology and of the environment, the participating States declare that they will take from now on concrete steps in this process by identifying, developing and carrying out, with the participation of their competent organizations, enterprises and firms, projects of common interst, inter alia in the following areas:

- transport and communications, including their infrastructure;

- informatics;

- exchange of economic and commercial information, including statistics;

- standardization and certification of products;

- energy;

- mining and processing of mineral raw materials;

- tourism;

- agriculture and agro-indusries;

- veterinary and sanitary protection;

- health care and pharmaceutics;

- science and technology.

14- In order to promote their co-operation, the participating States will act to improve the business environment and to stimulate individual and encouraging direct contacts among enterprises and firms directly involved, mainly by:

- facilitating, via bilateral negotiations, the prompt entry, stay and free movement of businessmen in their respective territories and encouraging direct contacts among 
enterprises and firms;

- providing support for small and medium-sized enterprises;

- contributing to the expansion of their mutual trade in goods and services and ensuring conditions favorable to such development by continuing their efforts to further reduce or progressively eliminate obstacles of all kinds, in a manner not contravening their obligationss towards third parties;

- ensuring approriate conditions for investment, capital flows and different forms of industrial co-operation, notably by concluding and putting into effect, in the near future, agreements on the avoidance of double taxation and on the promotion and protection of investments;

- encouraging the exchange of information on international tenders organized in the participating States so as to give the opportunity to their entetrprises and firms to participate therein, in accordance with the natioanl rules and practices;

- encouraging co-operation in free economic zones.

15- The participating States will take appropriate steps, including by prom oting joint projects, for the protection of the enviroment, particularely the prreservation and the improvement of environment of the Black Sea, and the conservation, exploitation and development of its bio-productive potential.

16- The participating States will consider or encourage the conclusion of appropriate credit and financial arrangements at governmental and nongovernmental level and will seek to mobilize funds, including through international institujtions and third parties, for the purpose of expanding their mutual economic and commercial co-operation and implementing specific projects of common interest in the Black Sea. In this context, they will consider the possibilities and the ways of estabhlishing a "Black Sea Foreign Trade and Investment Bank".

17- Meetings of the Foreign Ministers of the participating States will be convened regularly on rotation basis, at leasyt once a year-, to review progress and to define new targets. By common understanding, ad hoc and permanent working groups of experts are to be set up to propose the necessary arrangements concerning the cooperation in different fields. The participating States consider that at this stage of the business community should be invited to this process so as to benefit from their practical experience.

18- Those States which commit tehmselves to the observance of the provisions of the present document can join, with the approval of the participating States, the whole process of co-operation. Organizations, enterprises and firms of third parties will also be given the possibility of indicating their implementation. Regional and international 
economic and financial institutions may also contribute in the cartrying out of these projects.

\section{Endnotes}

1 Lippert, B. and Schneider, H. (eds.) (1995), Monitoring Association and Beyond: The European Union and Visegrád States.

2 For more details, see Meier, C. (1994), "Cooperation Initiatives in Eastern Central Europe", pp. 254-262.

3 Kirichenko, V. (1994), "The State of and Prospects for Economic Ties in the CIS", pp. 39-56; and Zevin, L. (1995), "The Economic Space of the CIS: Possible Paths of Organization", pp. 6-19.

4 Zagorski, A. (1994), "Reintegration in the former USSR?", pp. 263-272.

5 Von Loringhoven, A. F. F. (1998), "Regional Cooperation: Building Bridges as Europe Grows Together", pp. 12-17.

6 De Cordier, B. (1996), "The Economic Organization: towards a new silk road on the ruins of the Cold War?", pp. 47-57; and Dieter, H. (1996), "Regional integration in central Asia: current economic position and prospects", pp. 369386.

7 Gençkaya, O. F. (1993), "The Black Sea economic co-operation project: A regional challenge to European integration", pp. 550-551.

8 Volkan, E. (1995), " Black Sea Trade and Development Bank", pp. 66-61; and New Europe (1999), "Black Sea Bank starts operations", p. 1.

9 The EBRD was established in 1990 by 41 initial subscriber, who became its members. The subscribers consisted of 39 countries and the EU and the European Investment Bank. The main object of the institution is to foster the transition to market orientated economics and the promotion of private sector initiatives in Central and Eastern Europe. Its structure and modus operandi closely resembles that of the European Investment Bank. Though the Bank is not strictly an EU institution, it nevertheless reflects EU policy towards Central and Eastern Europe. See Lasok, D. (1992), "Institutional Issues:

Participation in Community Institutions", Marmara Journal of European Studies, Vol. 2, No. 1-2, p. 66.

10 For more details, see MacFarlane, S. N. (1995), "The Structure of Instability in the Caucasus", pp. 380-393; and Özer, E. (1997), "The Black Sea Economic 
Co-operation and Regional Security", pp. 76-106;

11 Gall, C. (1998), "Peace Deal Eludes Ethnic Conflict", p. 14.

12 Balkır, C. (1993), Karadeniz Ekonomik işbirliği Bölgesi; and Dartan, M. (1992a), "Karadeniz Ekonomik__birli_i: Türkiye Lokomotif", pp. 32-35.

13 See, for example, Dartan, M. (1992b), "Azerbaycan'ın Ekonomik Yapısı ve Piyasa Ekonomisine Geçiş Dönemi Sorunları_", pp. 86-93.

14 Dartan, M., (1992a), p. 34.

15 DEIK Bulletin, 1997, Turkey and BSEC Countries, p. 7.

16 Demirsar, M., (1995), "BSEC Reviews Telecommunications, Transport and Energy Project", p. B1.

17 Dartan, M., 1993/94, "Black Sea Economic Co-operation", pp. 140-141.

18 Sampson, M. W., 1995, "Black Sea Environmental Cooperation: States and the Most Seriously Degraded", pp. 59-60.

19 Dartan, M., 1993/94, p. 140.

20 Ibid., p. 140; Mee, L. (1997), "The Black Sea Environment and Ecosystem", pp. 339-341.

21 Özer, E. (1996), "The Black Sea Economic Co-operation and the EU", p. 86; for more details, see Özdamar, E. (1997), "Aquaculture Projects", pp. 369-374.

22 DEIK Bulletin (1997), Turkey and BSEC Countries, April, p. 7.

23 lbid. p. 7.

24 Russia is naturally anxious not to be excluded from the rich economic pickings offered by the oil and gas resources of the Caspian, Caucasus, and Central Asia. These reserves will play a key geo-political role during the next century, particularly if Gulf reserves become depleted. For Russia, exploitation of oil and natural gas holds the key to its re-industrialisation and the integration of its economy into the world economy. Russia lost much of its energy infrastructure when the Soviet Union broke up. Consequently, its refining capacity is not great enough to process the whole of its oil production. Russia also lost important oil exports to its former satellites. The energy sector remains important for Russia because it is a key source of foreign currency (along with the armaments industry), essential if Russia is to transform itself into a market economy. Moreover, Russia's energy sector (like its armaments sector) is one of the few 
parts if its economy benefiting from skilled workers and experienced managers. Furthermore, since Russia's energy sector employs such a large proportion of the working population (700,000 staff in Gasprom and 350,000 in Lukoil alone), the well-being of the sector has important social security implications (Rahr, A. (1997), "Die Sicherung der Energietransportwege: Eine strategische Aufgabe für Rußland", pp. 25-30).

25 The last collision in the Bosphorus left 12 crew dead and up to 16 missing. The collision, which had occurred near the Black Sea mouth of the strait and had caused an oil spill, cemented Turkey's fears concerning the danger posed by an increase in tanker traffic through the Bosphorus, one of the world's most crowded waterways. Had the wind direction changed, large scale pollution might have resulted (Financial Times (1994), "Pollution threat as tanker collision leaves 12 dead", 15 March).

${ }^{26}$ Fore more information see Albay, G. and Oral, N. (1998), "Turkey's Authority to Regulate Passage of Vessels Through the Turkish Straits", pp. 84-108.

27 MacLeod, S. / Meier, A. / Quinn-Judge, P. / Waller, D. and Zarakhovich, Y. (1998), "Black Gold", pp. 22-29; and Sampson, P. (1999), "Lubricating the Caspian", pp. 25-29.

28 The Shareholders of the AIOC are the following international companies; British Petroleum (UK - 17.3\%), Amoco (USA - 17.1\%), Socar (Azerbaijan $10 \%$ ), Lukoil (Russia - $10 \%$ ), Pennzoil (USA - $9.82 \%$ ), Unocal (USA - 9.52 $\%)$, Statoil (Norway - $8.5 \%$ ), Turkish Petroleum (Turkey - $6.75 \%$ ), Exxon (USA - $5 \%$ ), McDermott (USA - $2.45 \%$ ), Ramco (UK - $2.08 \%$ ), Delta-Nimir (Saudi Arabia - 1.68 \%) (Schmidt-Häuer, C.,1995, "Kalter Krieg ums Oil", p. 9).

${ }^{29}$ Akıncı, U. (1998), "Washington: Baku-Ceyhan Pipeline Not Possible in 1998", p. A4;

30 One such view was expressed during the "Oil in the Caspian Sea Region" conference held in Washington inMarch 1998, sponsored by the Friedrich Ebert Foundation. As Ross Wilson, speaking on behalf of the US State Department, explained; "the market wants flexibility and wants to keep options open for as long as possible. Foremost, no commitments should be made to major new export pipelines, multibillion dollar pipelines that might not be optimal, due to changing circumstances ... There is a lot of geological uncertainty ... No-one has any idea whether the oil that needs to flow out of Azerbaijan is going to be AIOC's production, a little bit more, or AlOC's production and a lot more? We will not know the answer until 2000, late 1999. Furthermore, untirl all of the tariffs and terms associated with various pipeline 
alternatives have been negotiated, or at least preliminarily, it is very hard to say if Baku-Ceyhan is the best way out? Is Baku-Ceyhan too expensive [you cannot say it yet...] (Akıncı, U. (1998), "Washington: Baku-Ceyhan Pipeline Not Possible in 1998", p. A4).

31 Gardner, D. (1998), "A New Road Map Iran", p. 19.

32 The Mullahs who led the 1979 revolution sought to prevent foreigners from gaining access to strateegic sectors of the Iranian economy. The 1981 Constitution was drafted to prohibit the granting of concessions to foreign capital in certain, key sectors. The oil and gas sector was, of course, the most poitically sensitive, given the troubled history of relations between Iran and western oil companies and the sheer size of its resource base. Iran possesses $9 \%$ of the world's known oil reserves and almost $16 \%$ of its natural gas (Corzine, R. and Allen, R. (1998), "Tehran reopens doors to vast oil and gas resources," p. 6).

33 Corzine, R. (1998), "Top companies lured by huge opportunity", p. 6.

34 Beddoes, Z.M. (1998), "Central Asia: A Caspian Oil", p. 7.

35 Many observers were surprised when, on 6 July 1998, Russia and kazakhstan signed an agreement dividing the northern portion of the Caspian seabed between them. The agreement paved the way for the development of Kazakhstan's potentially vast oil reserves there from October 1998. The agreement also marked Russia's first formal recognition of Kazakhstan's claims to the northern Caspain and was the first such bilateral agreement between any of the Caspian states. The effect of the agreement is that the Caspian will, in future, be treated in term of international law, less as a sea and more as lake, with its resources shared amongst the littoral states. Russia benefits from the agreement in a number of ways. Firstly, Russia maintains its hand in the ongoing negotiations concerning the resources of the region. Secondly, the agreement covers only the seabed and not the sea itself - pipelines and cable projects will thus be governed by later, separate agreements. On this point, some Kazakhs remain wary of their Russian neighbours. For one thing, acceptance of that principle might allow Russia to later veto a trans-Caspian pipeline if it were not to its liking. This might affect the Baku-Ceyhan route through Turkey. Virtually all of Kazakhstan's oil is currently exported via Russia (Clover, C. and Gall C. (1998), "Kazakhstan Free to Drill Huge Caspian Oilfield After Signing with Russia", p. 4).

36 Marer, P. (1994), "Economic Relations Between Eastern, Central, and Western Europe: An Historical Perspective", pp. 92-97 
37 lbid.

38 On December 13/14 1997, the EU issued a statement at the end of a two day meeting in Luxembourg in which it finalised its strategy for admitting up to 12. new members. The statement confirmed that detailed negotiations would start with the Czech Republic, Estonia, Hungary, Poland, Slovenia and Cyprus in early 1998. At the same time, preparations for membership negotiations would begin with Latvia, Lithuania, Slovakia, Romania and Bulgaria. If Bulgaria and Romania were to be admitted into the EU, three out of the eleven BSEC states would be EU members.

${ }^{39}$ See page 9

40 Turkey has made efforts to intensify its economic and commercial relations with the Islamic countries, under the umbrella of the OIC, which has more than 50 members.

41 The D-8 movement was initiated by the following countries to develop commercial and economic co-operation: Bangladesh, Egypt, Iran, Malaysia, Nigeria, Pakistan and Turkey.

\section{References}

Akıncı, U. (1998), "Washington: Baku-Ceyhan Pipeline Not Possible in 1998", Turkish Daily News, March 19, p. A4.

Albay, G. and Oral, N. (1998), Turkey's Authority to Regulate passage of Vessels through the Turkish Straits", Perceptions, Vol. 3, No. 2, pp. 84-108.

Bakos, G. (1993), "After COMECON: A Free Trade Area in Central Europe?", Europe-Asia Studies, Vol. 45, No. 6, pp. 1025-1044.

Balkır, C. (1993), Karadeniz Ekonomik Işbirliği, TÜSIAD publication: No. T/93, 5-159.

Beddoes, Z. M. (1998), "Central Asia: A Caspian Gamble", The Economist Survey, Februar 7-13.

BSEC Permanent International Secreteriat (1994), the BSEC: the Present and the Future, Istanbul.

Clover, C. and Gall, C. (1998), "Kazakhstan free to drill huge Caspian oilfield after signing pact with Russia", Financial Times, July 7, p. 4.

Corzine, R. and Allen, R. (1998), "Tehran reopens doors to vast oil and gas resources", Financial Times, p. 6. 
Dartan, M. (1992a), "Karadeniz Ekonomik Işbirliği: Türkiye Lokomotif, Görüş, No. 4, pp. 32-35.

Dartan, M. (1992b), "Azerbaycan'ın Ekonomik Yapısı ve Piyasa Ekonomisine Geçiş Dönemi Sorunları", in Istanbul Sanayi Odası (ISO), Bağımsız Devletler Topluluğu ve Orta Asya Cumhuriyetleri, No. 11, pp. 86-93.

Dartan, M. (1993/94), "Black Sea Economic Co-operation", Marmara Journal of European Studies, Vol. 3, No. 1-2, pp. 123-153.

De Cordier, B. (1996), "The Economic Cooperation Organization: towards a new Silk road on the ruins of the Cold War?", Central Asian Survey, Vol. 15, No. 1, pp. 4757.

Demirsar, M. (1995), "BSEC Reviews Telecommunications, Transport and Energy", Turkish Daily News, Section II, December 25.

Dış Ekonomik Iliş̧kiler Konseyi (DEiK), (1997), Turkey and BSEC Countries, April, Istanbul.

Dieter, H. (1996), "Regional integration in Central Asia: current economic position position and prospects", Central Asian Survey, Vol. 15, No. 3-4, pp. 369-386.

Financial Times, (1993), "Black Sea Bank for Thessalonika", 10 December.

Financial Times, (1994), "Pollution threat as tanker collision leaves 12 dead", 15 March.

Gall, C. (1998), "Peace Deal Eludes Ethnic", Financial Times Survey, March 3, p. 14.

Gardner, D. (1998), "A New Road Map Iran", Financial Times, June 19, p. 20.

Gençkaya, Ö. F. (1993), "The Black Sea economic co-operation project: A regional challenge to European integration", International Social Science Journal, Nr. 138, pp. 549-557.

Gumpel, W. (1993), "The Black Sea Economic Cooperation Zone: Outline of a New Community of states", Intereconomics, Vol: 28, No: 4, pp.178-182.

Haghayeghi, M. (1995), "Economic Cooperation Organization: A Preliminary Assessment", Central Asia Monitor, No. 1, pp. 15-19.

Kirichenko, V. (1994), "The State of and of Prospects for Economic Ties in the CIS", Problems of Economic Transition, Vol. 36, No. 39, pp. 39-56.

Kolat, A.Y. (1996), "Black Sea Economic Cooperation in Perspective", Eurasian Studies, Vol: 3, No: 3, pp.21-29.

Lasok, D. (1992), "Institutional Issues: Participation in Community Institutions", 
Marmara Journal of European Studies, Vol 2, No. 1-2, pp. 55-71.

Lippert, B. and Schneider, H. (eds.), (1995), Monitoring Association and Beyond: The European Union and Visegrád States, Europäische Schriften Politik, Bd. 74, Bonn.

MacLeod, S. / Meier, A. / Quinn-Judge, P. / Waller, D. and Zarakhovich, Y. (1998), "Black Gold", TIME, pp. 22-29.

MacFarlane, S. N. (1995), "The Structure of Instability in the Caucasus", Internationale Politik and Gesellschaft, No. 4, pp. 380-393.

Marer, P. (1994), "Economic Relations between Eastern, Central and Western Europe: An Historical Perspective", in Berend, I. T. (ed.), Transition to a Market Economy at the End of the 20th Century, Südosteuropa-Studien, Bd. 54, München, pp. 85-100.

Mee, L. (1997), "The Black Sea Environment and Ecosystem", This paper was prepared for the New Opportunities in the Black Sea Region conference held in Istanbul, April 28-30, and organised by the Black Sea Co-operation Business Council in Collaboration with Foreign Economic Relations Board of Turkey (DEIK), pp. 339-341.

Meier, C. (1994), "Cooperation Initiatives in Eastern Central Europe", Aussenpolitik, Vol. 45, No. 3, pp. 254-262.

Moorhouse, J. (1996), "Central and Eastern Europe: Accession to the European Union", Aussenpolitik, Vol. 47, No. 4, pp. 368-378.

New Europe, (1999), "Black Sea Bank starts operations", No. 313, May 24-30, p. 1.

Noetzold, J. (19959, "European Union and Eastern Central Europe: Expectations and Uncertainties", Aussenpolitik, Vol. 46, No. 1, pp. 14-23.

Özdamar, E. (1997), "Aquaculture Projects", This paper was prepared for the New Opportunities in the Black Sea Region conference held in Istanbul, April 28-30, and organised by the Black Sea Cooperation Business Council in Collaboration with Foreign Economic Board of Turkey (DEIK), pp. 368-374.

Özer, E. (1996), "The Black Sea Economic Co-operation and the EU", Perceptions, Vol. 1, No. 3, pp. 72-86.

Özer, E. (1997), "The Black Sea Economic Co-operation and Regional Security", Perceptions, Vol. 2, No. 3, pp. 76-106.

Rahr, A. (1997), "Die Sicherung der Energietransportwege: Eine strategische Aufgabe für Rußland", Internationale Politik, No. 1, pp. 25-30. 
Robinson, A. and Williams, S. (1998), "Shevardnadze Sees New Oill Pipeline as Key to Georgian Unity", Financial Times, July 3, p. 3.

Sampson, M. W. (1995), "Black Sea environmental Cooperation: States and the Most Seriously Degraded", Boğaziçi Journal, Vol. 9, No. 1, pp. 51-76.

Sampson, P. (1999), "Lubricating the Caspian", Transition, Vol. 6, No. 2, pp. 25-29.

Sarribrahimoğlu, L. (1996), "Gizli Belgelerle Boru Hatt_Bozgunu", Cumhuriyet, a series of research, from 14 to 20 July.

Schmidt-Häuer, C.(1995), "Kalter Krieg ums Oil", Die Zeit, June 16, pp. 9-10.

Tokgöz, E. (ed.) (1997), Gümrük Birliği Karadeniz Ekonomik Işbirliği ve Doğu Karadeniz Bölgesi, Türkiye Ekonomi Kurumu, Ankara.

Volkan, E. (1995), "Black Sea Trade and Development Bank", EKA International, pp. 60-61.

Von Loringhoven, A. F. (1988), "Regional Cooperation: building Bridges as Europe Grows Together", Aussenpolitik, Vol. 49, No. 1, pp. 12-17.

Zagorski, A. (1994), "Reintegration in the former USSR?", Aussenpolitik, Vol. 45, No. 3, pp. 263-272.

Zevin, L. (1995), "The Economic Space of the CIS", Problems of Economic Transition, Vol. 37, No. 9, pp. 6-19. 